\title{
Characterization of Tailor-Made Copolymers of Oligo(ethylene glycol) Methyl Ether Methacrylate and N,N-Dimethylaminoethyl Methacrylate as Nonviral Gene Transfer Agents: Influence of Macromolecular Structure on Gene Vector Particle Properties and Transfection Efficiency
}

\author{
Senta Üzgün, ${ }^{\dagger, \ddagger}$ Özgür Akdemir, ${ }^{\S}$ Günther Hasenpusch, ${ }^{\dagger}$ Christof Maucksch, ${ }^{\dagger, \ddagger}$ \\ Monika M. Golas, ,I, ${ }^{\prime}$ Bjoern Sander,",\# Holger Stark, ${ }^{\prime \prime, \nabla}$ Rabea Imker, ${ }^{\dagger}$ Jean-François Lutz, ${ }^{\S}$ \\ and Carsten Rudolph ${ }^{\star, \dagger, \ddagger}$ \\ Department of Pediatrics, Ludwig-Maximilians University, 80337 Munich, Germany, Department of \\ Pharmaceutical Technology, Free University of Berlin, 12169 Berlin, Germany, Fraunhofer Institute for \\ Applied Polymer Research, 14476 Potsdam-Golm, Germany, MPI for Biophysical Chemistry, 37077 \\ Goettingen, Germany, Institute of Anatomy, University of Aarhus, 8000 Aarhus C, Denmark, Stereology \\ and EM Research Laboratory, University of Aarhus, 8000 Aarhus C, Denmark, and Göttinger Zentrum für \\ Molekulare Biologie, Universität Göttingen, 37077 Göttingen, Germany
}

Received August 4, 2009; Revised Manuscript Received November 2, 2009

\begin{abstract}
Oligo(ethylene glycol) methyl ether methacrylates (OEGMA) of various chain lengths (i.e., 9, 23, or 45 EG units) and $N, N$-dimethylaminoethyl methacrylate (DMAEMA) were copolymerized by atom transfer radical polymerization (ATRP), yielding well-defined P(DMAEMA-co-OEGMA) copolymers with increasing OEGMA molar fractions $\left(F_{\mathrm{OEGMA}}\right)$ but a comparable degree of polymerization (DP $\sim 120$ ). Increase of both $F_{\text {OEGMA }}$ and OEGMA chain lengths correlated inversely with gene vector size, morphology, and zeta potential. P(DMAEMAco-OEGMA) copolymers prevented gene vector aggregation at high plasmid DNA (pDNA) concentrations in isotonic solution and did not induce cytotoxicity even at high concentrations. Transfection efficiency of the most efficient P(DMAEMA-co-OEGMA) copolymers was found to be $>10$-fold lower compared with branched polyethylenimine (PEI) $25 \mathrm{kDa}$. Although OEGMA copolymerization largely reduced gene vector binding with the cell surface, cellular internalization of the bound complexes was less affected. These observations suggest that inefficient endolysosomal escape limits transfection efficiency of P(DMAEMA-co-OEGMA) copolymer gene vectors. Despite this observation, optimized p(DMAEMA-co-OEGMA) gene vectors remained stable under conditions for in vivo application leading to 7-fold greater gene expression in the lungs compared with PEI. Tailor-made P(DMAEMA-co-OEGMA) copolymers are promising nonviral gene transfer agents that fulfill the requirements for successful in vivo gene delivery.
\end{abstract}

\section{Introduction}

Nonviral gene delivery systems are presently under development and investigation for the treatment of various inherited and acquired diseases such as cystic fibrosis, hemophilia, and cancer. Cationic polymers such as polyethylenimine (PEI) or poly $(N, N$-dimethylaminoethyl methacrylate) (P(DMAEMA) have been extensively studied as gene transfer agents in previous studies. ${ }^{1,2}$ These cationic polymers condense plasmid DNA (pDNA) into gene vector nanoparticles ${ }^{3}$ due to their high positive charge density and efficiently transfect cells in vitro. However, in vivo application is still limited due to (i) low biocompatibility, (ii) colloidal instability of gene vectors in physiological fluids at high concentrations, and (iii) rapid clearance from the bloodstream after systemic application. ${ }^{4}$

* To whom correspondence should be addressed. Tel.: (49) 8951607711. Fax: (49) 895160 7846. E-mail: carsten.rudolph@med.uni-muenchen.de.

Ludwig-Maximilians University.

Free University of Berlin.

${ }^{\S}$ Fraunhofer Institute for Applied Polymer Research.

"MPI for Biophysical Chemistry.

${ }^{\perp}$ Institute of Anatomy, University of Aarhus.

\# EM Research Laboratory, University of Aarhus.

$\nabla$ Universität Göttingen.
Successful gene therapy requires a gene transfer system that efficiently delivers the transgene into the diseased cell, remains colloidally stable at high pDNA concentrations, and avoids inducing adverse effects.

P(DMAEMA) was chosen as the polymer lead structure for oligo(ethylene glycol) (OEG) modification because it has been previously shown to fulfill at least two of these requirements, that is, gene transfer efficiency comparable with the "gold standard" branched PEI $25 \mathrm{kDa}$ without causing equally serious toxicity. ${ }^{5}$ Moreover, P(DMAEMA) is a water-soluble polymer containing tertiary amino side groups that efficiently condense pDNA into nanoparticles. ${ }^{2,6}$ The polymer was first described in 1996 by Cherng and co-workers. ${ }^{7}$ Subsequently, various factors affecting gene transfer efficiency and cytotoxicity were identified, such as (i) molecular weight and molecular weight distribution, ${ }^{8,9}$ (ii) polymer and gene vector composition, such as polymer/pDNA ratio, ${ }^{8,9}$ and (iii) formulation methods, ${ }^{10}$ as well as, (iv) transfection parameters such as incubation time and transfection in the absence or presence of serum albumin. ${ }^{9}$ Optimum transfection efficiency was found at polymer/pDNA ratios of $3-5 / 1(\mathrm{w} / \mathrm{w})$ corresponding to an N/P ratio (which is defined as the ratio between polymeric nitrogen residues and pDNA phosphate groups) of 5-8/1 using high molecular weight 
polymers ( $>300 \mathrm{kDa})$. Under these conditions, small particles of $200 \mathrm{~nm}$ with a positive surface charge were formed. ${ }^{7,9}$ In addition, a typical bell-shaped relationship between transfection efficiency and polymer/pDNA ratio was observed which was ascribed to ineffective condensation at low polymer/pDNA ratio and cytotoxicity of the polymer with increasing polymer concentrations at high polymer/pDNA ratio, either in its free or complexed form with pDNA. ${ }^{11}$

Although cationic polymers exhibit efficient pDNA condensation that leads to efficient cellular uptake of the resulting gene vector particles, their high positive charge density contributes to their high cytotoxicity, which is among the major limiting factors for in vivo application. ${ }^{12}$ Although the high number of cationic charges can be partially masked by pDNA condensation, ${ }^{9}$ unspecific interactions with blood components, vessel endothelia, and plasma proteins occur upon intravenous injection of cationic gene vectors, which leads to aggregation, activation of the complement system and finally rapid clearance of the gene vectors from the bloodstream. ${ }^{13,14}$ In fact, it has been previously reported that tissue distribution of cationic gene vectors, especially the high transfection efficiency of P(DMAEMA) or PEI in the lungs, can be ascribed to the formation of aggregates formed with blood cells and plasma proteins after intravenous administration followed by enhanced deposition in the capillary bed of the lungs (physical trapping). ${ }^{4,15-17}$ On the other hand, a positive charge and a small size are critical for cell surface binding and internalization, which most likely takes place via nonspecific adsorptive endocytosis. ${ }^{18,19}$

Moreover, relatively high concentrations of pDNA are indispensable for in vivo gene vector application. Earlier studies revealed that stable $\mathrm{P}(\mathrm{DMAEMA}) / \mathrm{pDNA}$ particles are formed up to a concentration of $40 \mu \mathrm{g} / \mathrm{mL}$ at physiological $\mathrm{pH}$, however, at pDNA concentration $>40 \mu \mathrm{g} / \mathrm{mL}$ aggregation occurred. It has been reported that lowering the $\mathrm{pH}$ of the solution can enhance charge density of P(DMAEMA) and condensation properties, hence, increasing colloidal stability. ${ }^{20}$ Indeed, concentrated gene vector suspensions with pDNA concentrations up to $200 \mu \mathrm{g} / \mathrm{mL}$ can be formed only under nonphysiological $\mathrm{pH}(\mathrm{pH}$ 5.7) in the presence of $20 \%$ sucrose and at low ionic strength. ${ }^{10}$

The aforementioned problems emphasize the need for the design of novel gene transfer agents to encounter these limitations. A common approach to efficiently shield the positive surface charge of the gene vectors takes advantage of introduction of hydrophilic, noncondensing moieties such as poly(ethylene glycol) (PEG), ${ }^{21} \mathrm{~N}$-vinyl-pyrrolidone (NVP), ${ }^{9}$ and poly $[N$ (2-hydroxypropyl) methacrylamide] (HPMC) ${ }^{22}$ into the cationic polymer scaffold. This so-called "PEGylation" of cationic polymers such as PEI, poly-L-lysin (PLL) and P(DMAEMA) led to block ${ }^{23-27}$ or graft copolymers, ${ }^{18,28,29}$ as well as, postPEGylated gene vector particles ${ }^{17,30-32}$ and ternary PEGmodified gene vector complexes. ${ }^{30}$ PEGylation resulted in (i) reduction of cytotoxicity in vitro and in vivo, (ii) improved water solubility and colloidal particle stability, (iii) decreased chargedependent interactions with plasma proteins or circulating cells, and (iv) increased circulation time in the bloodstream. Finally, PEG-graftment has been successfully used as a spacer moiety between a targeting ligand and a cationic polymer. ${ }^{21}$ Moreover, a phase I clinical trial using PEGylated PLL/pDNA complexes has been conducted in cystic fibrosis (CF) patients with some success in partial correction of the CF chloride transport defect, while no inflammatory response or other toxicity due to the gene vector was observed. ${ }^{33}$
Nevertheless, an ideal nonviral gene transfer agent has not been identified up to now. Gene delivery using P(DMAEMA)based gene vectors is a complex process and PEGylation may largely affect their physiochemical and biological activity but these processes have not been addressed in detail as has previously investigated for PEI-based gene vectors. ${ }^{23}$ Welldefined block copolymers based on polymethacrylates are currently in the focus for being applied in nonviral gene delivery. ${ }^{34,35}$ Our study aimed at providing a series of welldefined P(DMAEMA-co-OEGMA) copolymers with increasing OEG ratios and molecular weight via atom transfer radical polymerization (ATRP). This controlled radical polymerization technique allows synthesis of well-defined copolymers with predictable molecular weight, narrow molecular weight distribution, and controlled composition to address as accurately as possible known molecular weight requirements. ${ }^{8}$ In particular, influence of the macromolecular structure of the OEGMA copolymers (especially the influence of the OEG block) on their ability to condense pDNA and the physiochemical properties of the resulting gene vector particles were investigated in detail. In a second step, physiochemical properties were investigated in the context of the transfection efficiency of the gene vectors in vitro. Branched polyethylenimine (br-PEI), which is still the "gold-standard" cationic polymer, was used for comparison. ${ }^{1}$

\section{Materials and Methods}

Chemicals and Plasmid. TOTO-1 iodide was purchased from Moleculare Probes (Leiden, Netherlands), and Trypan Blue (\#T8154) and branched polyethylenimine (br-PEI; average molecular weight 25 $\mathrm{kDa}$ ) were obtained from Sigma-Aldrich (Schnelldorf, Germany) and used without further purification. Branched PEI was diluted in doubledistilled water and adjusted to $\mathrm{pH} 7$ with $\mathrm{HCl}$ (Merck Darmstadt, Germany). The plasmid pCMVLuc containing the Photinus pyralis luciferase gene under the control of the cytomegalovirus immediate early promotor (CMV) was kindly provided by Prof. E. Wagner (Department of Pharmacy, Ludwig Maximilians University, Munich, Germany). The CpG-free LucSh fusion gene coding for firefly $\mathrm{Lu}-$ ciferase and a zeocine resistance were provided from the pMOD-LucSh (Invitrogen, Toulose, France) and cloned into a pCpG-free backbone pCpG-mcs (Invitrogen, Toulose, France) to generate pCpG-Luc. Both plasmids pCMVLuc and pCpGLuc were propagated in Escherichia coli and purified by PlasmidFactory $\mathrm{GmbH}$ and Co. KG (Bielefeld, Germany). The purity of the plasmids were $\leq 0.1$ E.U./ $\mu \mathrm{g}$ DNA, the amount of supercoiled pDNA was $\geq 90 \%$ ccc (covalently closed circular) and $>98 \% \mathrm{ccc}$ for the pCMVLuc and the pCpGLuc plasmid, respectively.

Cell Lines. Two different adherent cell lines (BEAS 2B, MLE 12) were used to evaluate the biological activity of the polymers. BEAS2B (human bronchial epithelia cell line) and MLE-12 (mouse alveolar epithelial cell line) were obtained from the ATCC (American Type Culture Collection, Wesel, Germany). Both cell lines were cultured in minimum essential medium (MEM, Gibco-BRL, Karlsruhe, Germany) supplemented with $10 \%$ fetal calf serum (FCS, Gibco-BRL, Karlsruhe, Germany). For bioactivity studies, the cells were grown to $80 \%$ confluency at $37{ }^{\circ} \mathrm{C}$ in a $5 \% \mathrm{CO}_{2}$ humidified air atmosphere.

Animals. Female Balb/C mice (7 weeks old; Elevage Janvier, Le Genest Saint Isle, France) were used for intratracheal application. The mice were maintained under specific pathogen-free conditions and acclimatized to the new environment in the animal facility at least seven days prior to the experiment. Animal procedures were permitted by the local ethics committee and performed according to the German law "Guidelines of protection of animal life".

Synthesis and Characterization of P(DMAEMA-co-OEGMA) Copolymers. In a typical polymerization experiment, copper(I) bromide ( 1 equiv) and 2,2' bipyridyl ( 2 equiv) were added to a Schlenk tube. 
The tube was sealed with a rubber septum and subsequently purged with dry argon for $20 \mathrm{~min}$. Then, a degassed mixture of OEGMA (120 $-n$ equiv), DMAEMA ( $n$ equiv), and ethanol (monomers/solvent $\sim$ $1: 1.25 \mathrm{v} / \mathrm{v}$ ) were added through the septum with a degassed syringe. Finally, the initiator methyl 2-bromopropionate (1 equiv) was added through the septum with the help of a microliter syringe. The mixture was transferred into a thermostatted oil bath and was heated at $60{ }^{\circ} \mathrm{C}$ for $8 \mathrm{~h}$. The experiment was stopped by opening the tube and exposing the catalyst to air. At this stage, the raw polymerization mixture was analyzed by ${ }^{1} \mathrm{H} \mathrm{NMR}$ in $\mathrm{CDCl}_{3}$. Monomer conversions were calculated from the NMR spectrum by comparing the integrations of the vinyl protons of the remaining monomers $(5.50$ and $6.05 \mathrm{ppm})$ to the overall integration of the region $3.85-4.40 \mathrm{ppm}$, where resonates two protons of the remaining monomers and two protons of the formed polymers. The raw polymerization mixture was diluted with ethanol and passed through a short silica column (60-200 mesh) to remove the copper catalyst. Then, the filtered solution was diluted with deionized water and subsequently purified by dialysis in water (Roth, ZelluTrans membrane, molecular weight cutoff: 4000-6000). Last, water was removed by rotary evaporation. The formed copolymers P(DMAEMAco-OEGMA) appeared as yellowish oils and were characterized by size exclusion chromatography (SEC) and ${ }^{1} \mathrm{H}$ NMR. Molecular weights and molecular weight distributions were measured by SEC performed either at $25{ }^{\circ} \mathrm{C}$ in tetrahydrofuran (THF) or at $70{ }^{\circ} \mathrm{C}$ in $\mathrm{N}$-methylpyrollidone (NMP; flow rate was $1 \mathrm{~mL} \cdot \mathrm{min}^{-1}$ in all cases). For calibration, linear polystyrene standards (PSS Germany) were used. The comonomer composition (e.g., the molar fraction of OEGMA in the copolymer $\left.F_{\text {OEGMA }}\right)$ of the formed copolymers was determined by NMR by comparing the integration of specific protons of the OEGMA monomer units with those of DMAEMA units. For example, one approach is to compare the integration of the methoxy protons of the OEGMA units $(3.35 \mathrm{ppm})$ to the overall integration of the region $3.85-4.35 \mathrm{ppm}$, where resonates two protons of the OEGMA units and two protons of the DMAEMA units. For these copolymers, we selected the following nomenclature: $\mathrm{P}\left(\mathrm{DMAEMA}_{n}-\mathrm{co}-\mathrm{OEGMA}(X)_{m}\right)$, where $X$ represents the number of EG units of the OEGMA monomer $(X=9,23$, and $45 \mathrm{EG}$ units). The indexes $n$ and $m$ denote the average number of DMAEMA and OEGMA monomers per P(DMAEMA-co-OEGMA) copolymer, respectively.

Preparation of Polymer-Plasmid DNA Complexes. Stock solutions of P(DMAEMA)-co-OEGMA copolymer series were prepared in double distilled water. For transfection experiments, pDNA and polymer stock solutions were diluted separately in $25 \mu \mathrm{L}$ of Hepes Buffered Saline (HBS, $150 \mathrm{mM} \mathrm{NaCl}, 10 \mathrm{mM}$ Hepes, $\mathrm{pH}$ 7.4). Plasmid DNA solution was added to the polymer solution and mixed gently by pipetting up and down 5-8 times, resulting in different N/P ratios (defined as the ratio between polymeric nitrogen residues and DNA phosphate groups) with a final pDNA concentration of $20 \mu \mathrm{g}$ pDNA per $\mathrm{mL}$. Subsequently, gene transfer complexes were incubated for 20 min at room temperature prior to further use.

Size and Zeta Potential Measurements. Particle size (determined by dynamic light scattering DLS) and zeta potential of the polymer-pDNA complexes were measured using a Zeta Potential Analyzer with a solid state laser operating at $30 \mathrm{~mW}$ (Brookhaven Instruments Corporation, Vienna, Austria). Complexes were prepared in double-distilled water at a N/P ratio of 20:1, as described above. Plasmid DNA concentration was fixed at $20 \mu \mathrm{g} / \mathrm{mL}$. Complexes were incubated for $20 \mathrm{~min}$ before measurement. Measurements were performed at $25{ }^{\circ} \mathrm{C}$ using the following settings: 5 subruns (particle size) and 10 subruns (zeta potential); the viscosity $(0.89 \mathrm{cP})$; refractive index (1.333) of water; and beam mode $\mathrm{F}(\mathrm{Ka})=1.50$ (Smoluchowsky). The instrument was calibrated using polystyrene latex suspension with a well-defined mean diameter of $92 \pm 3.7 \mathrm{~nm}$ (Duke Scientific Cooperation, CA) for size and Bl-LC-ZRZ reference of $-50 \pm 5 \mathrm{mV}$ (Laborchemie, Vienna, Austria) for zeta potential measurements. Results are given as mean hydrodynamic diameter $(\mathrm{nm}) \pm$ standard error (intensity distribution) or zeta potential $(\mathrm{mV}) \pm$ standard error. In addition, the homogeneity of the particle sizes is expressed by the polydispersity index (PI), which ranges from smaller than 0.2 for a homogeneous up to 1.0 for a heterogeneous size distribution.

To study the influence of salt concentration on particle stability (colloidal stability assay), a 10-fold concentrated HBS solution was used to adjust the required salt concentration. Subsequently, particles size was analyzed every $5 \mathrm{~min}$ at $25^{\circ} \mathrm{C}$ using the following settings: 10 subrun measurements per sample; the viscosity of HBS (1.44 cPa), refractive index (1.333).

Agarose Gel Retardation Assay. The extent of DNA binding and condensation by the novel copolymers were investigated by electrophoresis on agarose gel. Briefly, polyplexes were formed at varying N/P ratios in HBS as described above (see Preparation of Polymer-Plasmid DNA Complexes), mixed with $6 \times$ loading buffer $(0.25 \%$ bromphenol blue, $0.25 \%$ xylene cyanol FF, $30 \%$ glycerol in water), applied in the slots of a $0.8 \%$ agarose gel, and run at $120 \mathrm{~V}$ for $1.5 \mathrm{~h}$. The amount of unbound pDNA in agarose gel electrophoresis was analyzed with AIDA Image Analyzer Software (Raytest, Straubenhardt, Germany). Band intensity of free sc pDNA was set as $100 \%$ unbound pDNA.

Fluorescence Quenching Assay. Plasmid DNA was labeled with the bisintercalating dye TOTO-1 iodide (1 molecule of TOTO- 1 per 20 base pairs of the nucleotide). ${ }^{36}$ Plasmid DNA/polymer complexes were formed by adding equal volumes of TOTO- 1 labeled pDNA $(0.25$ $\mu \mathrm{g} / 50 \mu \mathrm{L}$ solvent in each well) to the polymer solution (final N/P ratio of 20) in 96-well plates and incubating for $20 \mathrm{~min}$ at room temperature. Fluorescence intensity of TOTO-1 was measured at 25 ${ }^{\circ} \mathrm{C}$ on a Wallac Victor ${ }^{2} / 1420$ Multilabel Counter (Perkin-Elmer, Rodgau-Juegesheim, Germany) using an excitation wavelength $\left(\lambda_{\mathrm{ex}}\right)$ of $485 \mathrm{~nm}$ and an emission wavelength $\left(\lambda_{\mathrm{em}}\right)$ of $535 \mathrm{~nm}$. The fluorescence intensity was measured for HBS background $\left(F_{\text {back }}\right)$, TOTO-1 labeled pDNA ( $\left.F_{\mathrm{DNA}}\right)$, and gene vectors containing TOTO-1 labeled pDNA $\left(F_{\mathrm{pol}}\right)$ at $25{ }^{\circ} \mathrm{C}$. Triplicates were used for each measurement. The percentage of quenching was calculated as follows:

$$
Q[\%]=\left[\left(F_{\text {pol }}-F_{\text {back }}\right) /\left(F_{\text {DNA }}-F_{\text {back }}\right)\right] \times 100 \%
$$

Negative Staining of Polymer-pDNA Complexes. For electron microscopy analysis, complexes were formed at an N/P ratio of 20 in HBS with a final pDNA concentrations of $20 \mu \mathrm{g} / \mathrm{mL}$ (see above). Samples were prepared freshly and incubated at room temperature for 20 min prior to the preparation of electron microscopy specimens. To this end, about $25 \mu \mathrm{L}$ of the samples were filled into wells of a Polyoximethylen black plastic block and particles were adsorbed for 90 s onto a $3 \times 3 \mathrm{~mm}$ piece of carbon film. The carbon film was then transferred to a second well filled with $2 \%$ aqueous uranyl format solution for 2 min and was picked up from the staining solution by putting a cooper grid covered with a holey carbon film on top of the floating carbon film. ${ }^{37}$ After blotting the excess liquid, the grid was dried and stored at room temperature. Specimens were imaged using a CM200 FEG electron microscope (Philips/FEI, Eindhoven, Netherlands). Images were taken at room temperature on a $4 \mathrm{k} 4 \mathrm{k}$ chargecoupled device (CCD) camera (TVIPS, Gauting, Germany) with 2-fold pixel-coarsening. Particle dimensions were determined using the software EMMENU of TVIPS.

Native Cryo Preparation of Vitrified Specimens. Identical samples of the pDNA-polymer complexes in HBS used for negative staining electron microscopy were also subjected to vitrification for native cryo electron microscopy without staining. A total of $5 \mu \mathrm{L}$ of the samples were pipetted onto a glow-discharged electron microscopic grid covered with a holey carbon film. After briefly blotting the excess liquid, the grid was rapidly freeze-plunged into liquid ethane and stored in liquid nitrogen until imaging. ${ }^{38}$ Images were taken at liquid nitrogen conditions using a CM200 FEG electron microscope equipped with a Gatan cryoholder (Gatan $\mathrm{GmbH}$, Munich, Germany). For electron microscopical analysis, a CCD camera (TVIPS) was used and particle dimensions were determined using the EMMENU software.

Determination of Metabolic Cytotoxicity. Cytotoxicity of P(DMAEMA) and P(DMAEMA-co-OEGMA) polymers was analyzed in 96-well plates on BEAS-2B cells. Cells were seeded with a density of 
20000 cells per well in quadruples into 96-well plates. Different polymer concentrations $(16-500 \mu \mathrm{g} / \mu \mathrm{L})$ dissolved in MEM $+10 \%$ FCS were added to the cells. After $24 \mathrm{~h}$ of incubation $\left(37^{\circ} \mathrm{C}\right.$, in a humidified $5 \%$ $\mathrm{CO}_{2}$-containing atmosphere), the number of viable cells was analyzed using a PerkinElmer ATPlite Luminescence Detection Assay System (PerkinElmer, Boston, MA) according to the manufacturer's instructions. Untreated cells were used as a reference by setting the corresponding luminescence to $100 \%$ viable cells.

Transfection Experiments and Luciferase Activity Measurements. For transfection, 20000 and 100000 cells were seeded $24 \mathrm{~h}$ before transfection in each well of a 96- and 24-well plate, respectively (TPP, Trasadingen, Switzerland). Cells were rinsed with PBS (GibcoBRL, Karlsruhe, Germany) immediately before transfection. A total of $200 \mu \mathrm{L}$ of fresh serum-free medium were added per well and, subsequently, $50 \mu \mathrm{L}$ of the gene vector complexes prepared as described above corresponding to $0.25 \mu \mathrm{g}$ and $1 \mu \mathrm{g}$ of pDNA per 96 and 24 wells, respectively, were added. After $4 \mathrm{~h}$ of incubation at $37{ }^{\circ} \mathrm{C}$ in a humidified $5 \% \mathrm{CO}_{2}$-containing atmosphere, the transfection medium was replaced with MEM, including $10 \%$ FCS supplemented with $0.1 \%$ $(\mathrm{v} / \mathrm{v})$ penicillin/streptomycin and $0.5 \%(\mathrm{v} / \mathrm{v})$ gentamycin (Gibco-BRL, Karlsruhe, Germany). A total of $24 \mathrm{~h}$ post-transfection, luciferase activity was measured in relative light units (RLU) using a Wallac Victor $^{2} 1420$ Multilabel Counter (Perkin-Elmer, Boston, MA) according to Huth et al. ${ }^{39}$ Results were normalized to total cell protein using the BioRad Protein Assay (BioRad, Munich, Germany) and bovine serum albumin as protein standard.

Flow Cytometry Analysis. Flow cytometry analysis was used to distinguish between associated and internalized fluorescently labeled polymer-pDNA complexes in BEAS-2B cells. Flow cytometry has been previously used to distinguish between surface associated and internalized gene vector particles. The percentage of fluorescent cells and their mean fluorescence intensity were determined using a FACScan flow cytometer (Becton Dickinson, San Jose, CA) equipped with a 488 $\mathrm{nm}$ air-cooled argon ion laser. The viable cells were further differentiated from nonviable ones by staining with propidium iodide (PI, Molecular Probes, Leiden, Netherlands). A minimum of 2000 cells was measured in each sample using forward scatter, side scatter, and filter settings for emission at $530 \pm 30 \mathrm{~nm}$ (FL1) to detect TOTO-1 labeled pDNA and $585 \pm 42 \mathrm{~nm}$ (FL2) to detect propidium iodide positive cells.

A useful, fast, and reliable method has been described by Hed et al. ${ }^{40}$ For this purpose, gene vector pDNA was fluorescence-labeled with the bisintercalating dye TOTO-1 before transfection and gene vectors were formed as described previously and added to BEAS-2B cells for $1 \mathrm{~h}$ at $37^{\circ} \mathrm{C}$ as described for transfection. Before analysis, cells were rinsed with PBS and dislodged from the wells by 8 min incubation with $100 \mu \mathrm{L}$ of trypsin, $0.05 \%(1 \times)$ with EDTA (Gibco-Invitrogen, Karlsruhe, Germany) at $37{ }^{\circ} \mathrm{C}$ to generate single-cell suspensions. The cells were collected in a tube and stored on ice prior to flow cytometric analysis. After addition of cell impermeable TOTO-1 fluorescence quenching reagents such as crystal violet ${ }^{40}$ or trypan blue, ${ }^{41,42}$ the ratio of cell surface bound to internalized gene vectors can be estimated. These reagents cause quenching of cell surface attached TOTO-1 gene vector fluorescence only without affecting the fluorescence intensity of internalized gene vector complexes. Hence, this method allows to distinguish between the ratio of cell surface associated and internalized gene vector complexes. Trypan blue added to cells incubated with TOTO-1 labeled P(DMAEMA) gene vector complexes at a concentration $>0.15 \mathrm{mg} / \mathrm{mL}$ at $\mathrm{pH} 5$ and 7.4 resulted in a plateau of fluorescence positive cells with comparable mean fluorescence intensities (20 and $39 \%$ reduction of fluorescence positive cells and mean fluorescence intensity, respectively), indicating successful quenching of cell surface attached gene vectors only but not internalized gene vectors. No significant difference was observed for $\mathrm{pH} 5$ and 7.4, although it was reported that fluorescence quenching using trypan blue works better at lower $\mathrm{pH}^{41}$ Thus, the following experiments were all performed at $\mathrm{pH} 7.4$.
Another method to distinguish between adherent and internalized gene vector complexes has been described previously. ${ }^{43}$ Fluorescencelabeled gene vector particles that are attached to the cell surface via electrostatic interactions can be efficiently removed using CellScrub washing buffer (GeneTherapy Systems, San Diego, CA) for $15 \mathrm{~min}$ at room temperature according to the manufacturer's instructions. Thus, this approach allows to discriminate between extracellularly bound and internalized complexes. ${ }^{44,45}$ Indeed, the number of fluorescence positive cells decreased $20 \%$ after additional incubation of CellsScrub washing buffer (cellular internalization) compared to the number of fluorescence positive cells after washing with PBS (cellular association) alone. Similar observations were made for the mean fluorescence intensity with a decrease of $32 \%$. These observations indicated that this procedure allowed to remove cell surface bound gene vectors.

In Vivo Application. Gene vectors were generated as follows: plasmid DNA (pCpGLuc) and brPEI $25 \mathrm{kDa}$ or P[DMAEMA $80^{-} \mathrm{Co}-$ OEGMA $(9)_{40}$ ] copolymer were each diluted in $0.4 \mathrm{~mL}$ of HBS (HBS, $150 \mathrm{mM} \mathrm{NaCl}, 10 \mathrm{mM}$ Hepes, $\mathrm{pH}$ 7.4). Plasmid DNA solution was added to the polymer solution and mixed gently by pipetting up and down 5-8 times, resulting in a final pDNA concentration of $12.5 \mu \mathrm{g}$ pDNA per $50 \mu \mathrm{L}$ and NP ratio of 10 and 20 for brPEI and P[DMAEMA $\left.{ }_{80}-\mathrm{co}-\mathrm{OEGMA}(9)_{40}\right]$ copolymer, respectively. Subsequently, gene transfer complexes were incubated for $20 \mathrm{~min}$ at room temperature prior to further use. The complexes were applied to Balb/C mice $(n=5)$ via an intratracheal administration route as described by Bivas-Benita et al. ${ }^{46}$ Mice were anesthesized with a mixture of medetomdiine $(11.5 \mu \mathrm{g} / \mathrm{kg})$, midazolam $(115 \mu \mathrm{g} / \mathrm{kg})$, and fentanyl $(1.15$ $\mu \mathrm{g} / \mathrm{kg}$ ) and suspended on a plate system (Hallowell EMC) at a $45^{\circ}$ angle by the upper teeth. A modified cold-light otoscope Beta 200 (Heine Optotechnik) was used to provide optimal illumination of the trachea, while a small spatula helped to open the lower jaw of the mouse and blunted forceps were used to displace the tongue for maximal oropharyngeal exposure. Subsequently, the tip of a Microsprayer Aerosolizer (Model 1A-1C and Aerosolizer FMJ-250, PennCenturyInc., Philadelphia, PA) was intratracheally inserted to apply $50 \mu \mathrm{L}$ of complexes, corresponding to $12.5 \mu \mathrm{g}$ plasmid DNA, to each mouse. The tip was withdrawn after $5 \mathrm{~s}$ and, subsequently, the mouse was taken off the support after $5 \mathrm{~min}$. Mice were again anaesthetized as described above after $24 \mathrm{~h}$, and afterward, the mice were given intraperitoneal injections of D-luciferin substrate dissolved in water and adjusted to $\mathrm{pH} 7$ ( $3 \mathrm{mg}$ in $100 \mu \mathrm{L} / \mathrm{mouse}$ ). After $10 \mathrm{~min}$, bioluminescence was measured (IVIS 100 imaging system; Xenogen, Alameda, CA) using the following camera settings: field of view 10, f1 f-stop, high resolution binning, and exposure time of $10 \mathrm{~min}$. The signal in the lung region was analyzed using Living Image Software version 2.50 (Xeniogen; Alameda, CA) and background subtracted.

\section{Results and Discussion}

Synthesis and Characterization of P(DMAEMA-coOEGMA) Copolymers. Tailor-made copolymers of OEGMA and DMAEMA were prepared by atom transfer radical polymerization. ${ }^{47,48}$ The role of the DMAEMA units in these copolymers is to form a complex with the negatively charged backbone of DNA. The role of the OEGMA units is to stabilize the formed polyplexes in aqueous medium and moreover to prevent immunological responses that might lead to an active removal of the polyplexes in vivo. Three different series of copolymers were prepared and characterized (Table 1). In these series, two main parameters were varied: (i) the chain-length of the OEG side chains (i.e., 9, 23, or 45 EG units) and (ii) the comonomer composition of the copolymers (i.e., the copolymers have a theoretical chain length of 120 in all cases, but have a variable DMAEMA/OEGMA composition). The objective of these comprehensive series is to identify the influence of the copolymer structure on the biological behavior of the gene carriers. 
Table 1. Properties of $P(D M A E M A-c o-O E G M A)$ Copolymers ${ }^{a}$

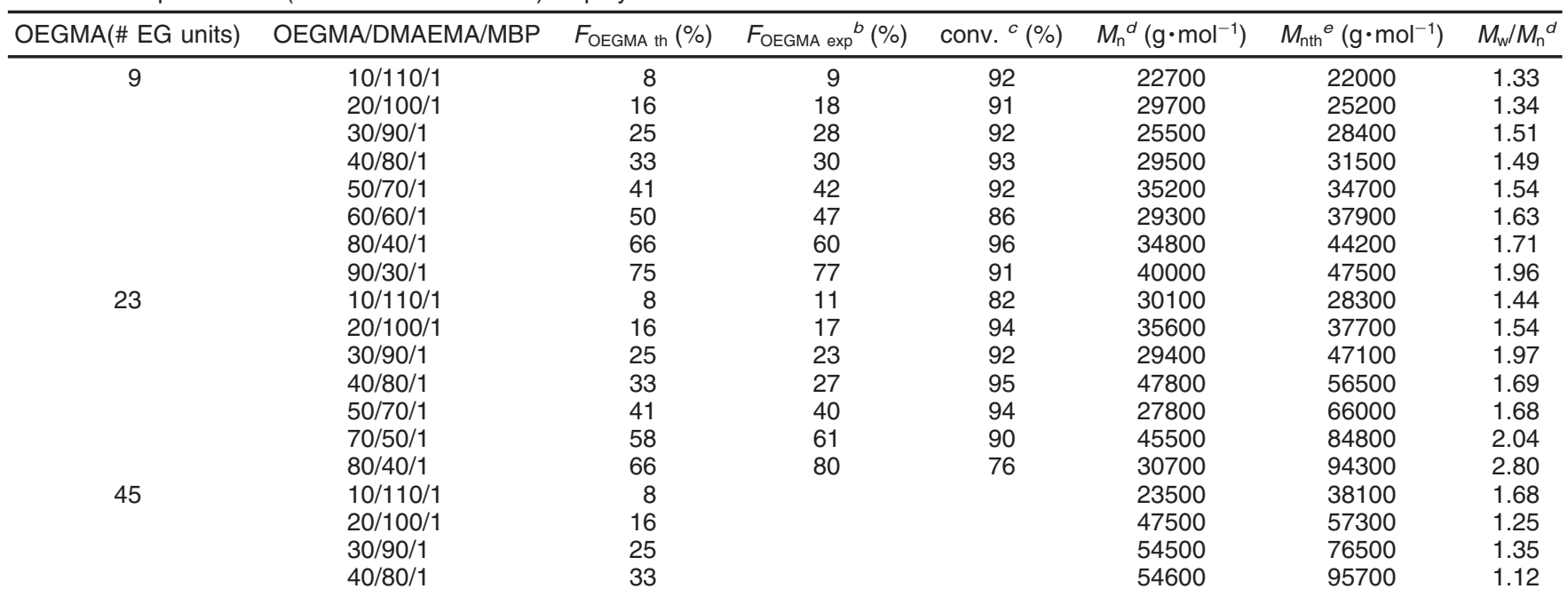

${ }^{a}$ The copolymers were synthesized by ATRP using methyl 2-bromopropionate (MBP) as an initiator and a combination of copper(I)Br and 2.2'bipyridyl as catalyst. All copolymerizations were performed in ethanol solutions at $60^{\circ} \mathrm{C}$. ${ }^{b}$ Calculated from the ${ }^{1} \mathrm{H}$ NMR spectra of the purified copolymers. ${ }^{c}$ Overall monomer conversion determined by ${ }^{1} \mathrm{H}$ NMR analysis of crude polymerization samples. ${ }^{d}$ Measured by SEC. ${ }^{e}$ Theoretical molecular weights calculated for complete monomers consumption.

All copolymers were synthesized using methyl 2-bromopropionate (MBP) as an initiator and a combination of copper(I) bromide and 2,2'-bipyridyl as catalyst. The copolymerizations were performed in ethanol solutions at $60{ }^{\circ} \mathrm{C}$. We recently reported that such conditions are ideal for preparing watersoluble polymers in a relatively short time. ${ }^{49,50}$ In all cases, copolymers P(DMAEMA-co-OEGMA) were isolated in high yields. Table 1 shows the properties of the synthesized polymers. ATRP allowed synthesis of relatively well-defined copolymers with controlled molecular weight and composition. Experimental molecular weights measured by SEC were in most cases relatively close to theoretical values. Still, for very long OEGMA side chains (e.g., 23 or 45 EG units), SEC molecular weights were found to be underestimated. This behavior is typical of copolymers with a high OEGMA content and is due to the strong differences in hydrodynamic volume between the studied polymers and the linear PS standards used for SEC calibration. ${ }^{49,51}$ Furthermore, in all cases, the experimental compositions were found to be close to the theoretical values (i.e., the initial composition OEGMA/DMAEMA in the initial comonomer feed). These results are indeed a direct consequence of the high monomer conversions reached in all experiments in the presence of the copper(I) bromide/2,2'-bipyridyl catalyst. On the other hand, this catalyst combination led in some cases to relatively broad molecular weight distributions. This situation can be improved with the use of a copper(I) chloride-based ATRP catalyst. ${ }^{49}$ Nevertheless, the control over chain polydispersity is not a parameter of crucial importance for the present study.

Complexation of pDNA with P(DMAEMA-co-OEGMA) Copolymers. The capacity of br-PEI, P(DMAEMA), and P(DMAEMA-co-OEGMA) copolymers to complex pDNA was studied by agarose gel retardation assay (Supporting Information, Figure 1A,B). The amount of free noncomplexed pDNA was calculated from DNA band intensities of unbound and complexed pDNA, respectively (Figure 1A,B). No free pDNA was observed for br-PEI and P(DMAEMA) at all N/P ratios tested indicating complete pDNA complexation (Supporting Information, Figure 1B). Plasmid DNA complexation by P(DMAEMAco-OEGMA) copolymers with low $F_{\text {OEGMA }}(\leq 50 \%)$ increased with increasing N/P ratios and decreased with increasing OEGMA molar ratio $\left(F_{\text {OEGMA }}\right)$ and molecular weight (EG units;
A

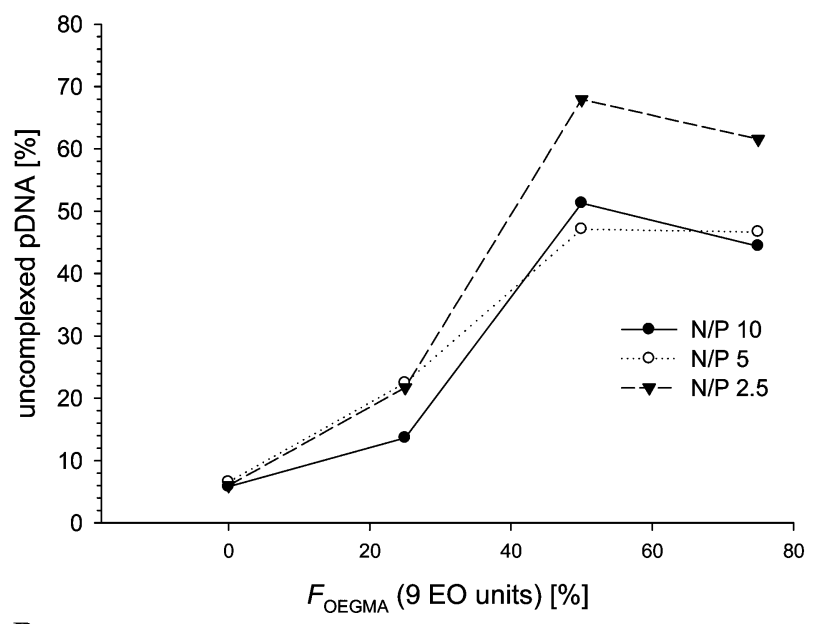

B

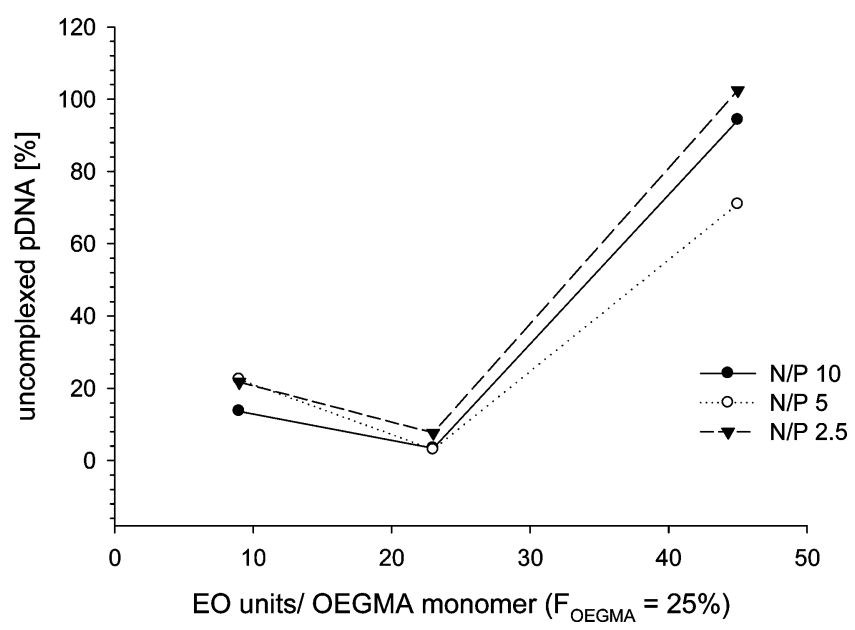

Figure 1. Agarose gel electrophoresis of P(DMAEMA-co-OEGMA) copolymers gene vector complexes at different N/P ratios. Quantitative analysis of unbound pDNA as a function of $(A) F_{\text {OEGMA }}$ (9 EO units) $(B)$ and ethylene oxide units/OEGMA $\left(F_{\text {OEGMA }}=25 \%\right)$. The amount of unbound pDNA in agarose gel electrophoresis was analyzed with AIDA Image Analyzer Software. Band intensity of free sc pDNA was set as $100 \%$ unbound pDNA. The graph shows pDNA binding and condensation properties at different N/P ratios. 
Table 2. Condensation of pDNA by P(DMAEMA-co-OEGMA) Copolymers ${ }^{a}$

\begin{tabular}{lccc}
\hline polymer & EG units & F $_{\text {OEGMA }}(\%)$ & quenching of residual fluorescence (\%) \\
\hline P(DMAEMA) & 0 & 0 & $66 \pm 2$ \\
P[DMAEMA 90 -co-OEGMA(9) $\left.)_{30}\right]$ & 9 & 25 & $82 \pm 4$ \\
P[DMAEMA & 75 -Co-OEGMA(9) & 750 & $107 \pm 3$ \\
P[DMAEMA & 9 & 25 & $108 \pm 11$ \\
br-PEI 25 kDa & 45 & 0 & $14 \pm 4$ \\
\hline
\end{tabular}

${ }^{\text {a }}$ Plasmid pDNA labeled with the bisintercalating dye TOTO-1 at a basepair-to-dye ratio 20:1 were complexed with P(DMAEMA-co-OEGMA) copolymers at an N/P ratio 20. Fluorescence intensity was measured in quadruble samples. The results represent the reduction in fluorescence intensity of pDNA condensed by the polymers compared to pDNA alone (\% quenching). This ratio is a measure for the pDNA condensing properties of the polymers.

Figure 1A,B). At high $F_{\text {OEGMA }}(>50 \%)$ pDNA complexation was abolished and free pDNA was present in the agarose gel for all N/P ratios tested (Supporting Information, Figure 1A, lanes $1-8)$. Only at low $F_{\text {OEGMA }}(16.7 \%)$ and low OEGMA molecular weight $(E G$ units $<9)$ pDNA migration was completely retarded (indicating complete DNA complexation) as observed for $\mathrm{P}($ DMAEMA). In general, complexation of pDNA decreased with increasing $F_{\mathrm{OEGMA}}$ and OEGMA chain length.

Further, interaction of P(DMAEMA), br-PEI, and P(DMAEMA-co-OEGMA) copolymers with pDNA was analyzed by fluorescence quenching assay (Table 2). The fluorescent bisintercalator TOTO-1 was used to monitor the formation of complexes in the presence of the cationic polymers. The quenching of the strong fluorescence signal can be taken as a measure for complex formation and vice versa the recovery of the fluorescence as an indication for complex disassembly. Branched PEI induced strong pDNA condensation, which was evident by a decrease of the initial TOTO-1-pDNA fluorescence intensity up to $86 \%$. In contrast, pDNA condensation was only moderate for P(DMAEMA) and further reduced for $\mathrm{P}(\mathrm{D}$ MAEMA-co-OEGMA) copolymers.

Agarose gel retardation and quenching assay demonstrated that reduction of the positive charge density of P(DMAEMA) together with introduction of sterically bulky OEGMA copolymers in the p(DMAEMA) scaffold reduced polymer binding to the negatively charged pDNA phosphate groups. These observations are in agreement with studies by Verbaan and colleagues, who observed that copolymers with a high degree of PEGgrafting (i.e., PEG $>22 \%$ ) were not capable of binding to pDNA. ${ }^{52}$ It has been argued that pDNA condensation is compromised in the presence of PEG moieties, which may adversely affect or even prevent interaction between the cationic block and pDNA due to an unfavorable entropy change. ${ }^{53}$ Different studies of P(DMAEMA)-based copolymers with varying hydrophobic/hydrophilic character further indicated that condensation of pDNA by cationic polymers is a cooperative process in which ionic and other types of interactions such as hydrogen bonding or hydrophobic interactions might be important. .,54 $^{-54}$

Size, Surface Charge, and Morphology of the P(DMAEMA-co-OEGMA) Gene Vectors. Particle size and surface charge of gene vectors are major determinants for transfection efficiency in vitro. ${ }^{7-9,55}$ It has previously been reported that negatively charged and large-sized P(DMAEMA)-pDNA gene vectors yielded only low transfection efficiency, whereas high transfection rates were observed for positively charged gene vectors of $150 \mathrm{~nm}$ diameter. Therefore, the influence of OEGMA-copolymerization on particle characteristics such as zeta potential and particle size together with colloidal stability was evaluated.

Size measurements using dynamic light scattering revealed that P(DMAEMA-co-OEGMA) copolymers form nanoparticles with pDNA with a narrow size distribution ( $\mathrm{PI}=0.167 \pm 0.085$ $-0.334 \pm 0.063)$, except for $\mathrm{P}\left(\mathrm{DMAEMA}_{90}-\mathrm{co}-\mathrm{OEGMA}(9)_{30}\right)$,
A
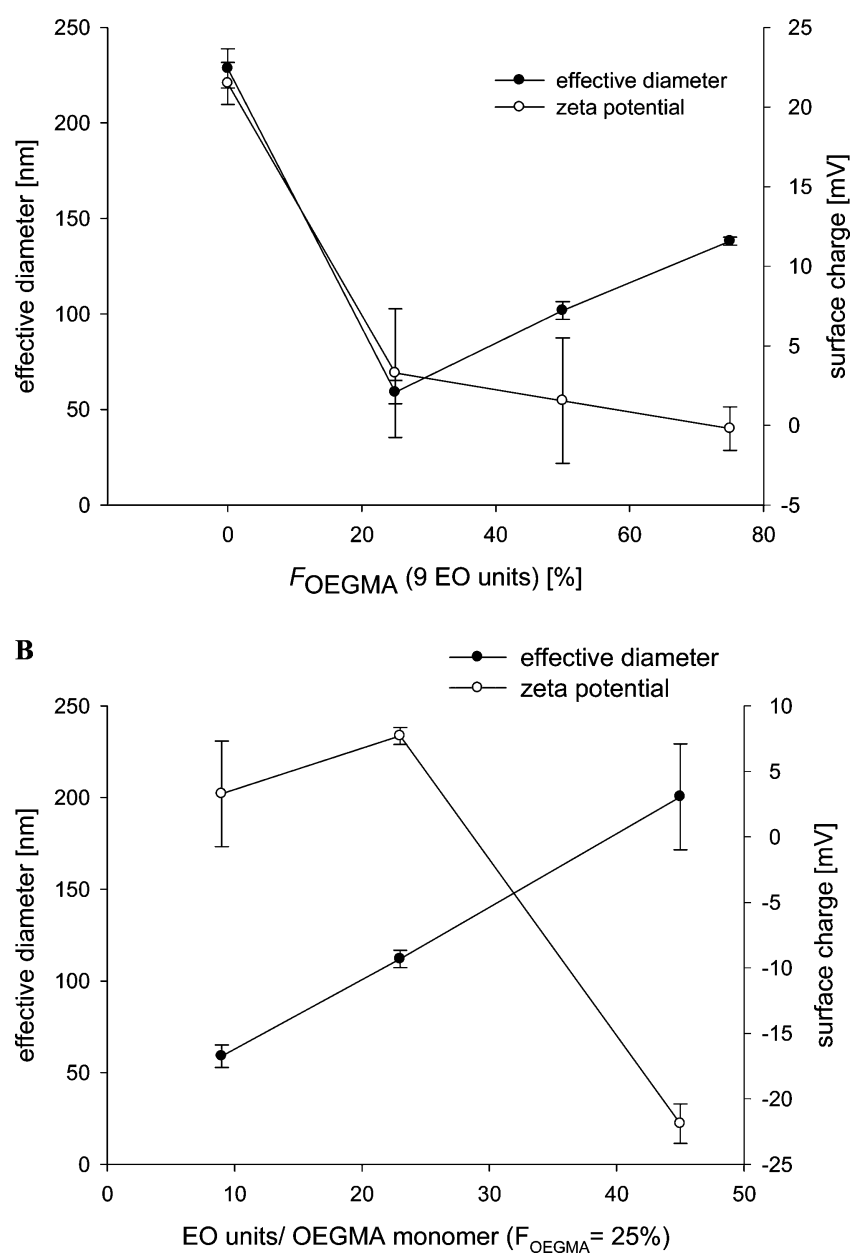

Figure 2. Particle size and zeta potential of $P(D M A E M A-c o-O E G M A)$ gene vector complexes as a function of (A) $F_{\text {OEGMA }}$ (9 EO units) (B) and ethylene oxide units/OEGMA $\left(F_{\mathrm{OEGMA}}=25 \%\right)$. Gene vectors were formed at an N/P ratio of 20 in distilled water (c(pDNA) $50 \mu \mathrm{g} / \mathrm{mL}$ ) and incubated for $20 \mathrm{~min}$ before measurement. The results represent the mean \pm SEM of 5 and 10 runs for particle size and zeta potential, respectively.

which showed a high PI $=0.677 \pm 0.241$. The particle size of the P(DMAEMA-co-OEGMA) gene vectors increased in a direct proportion to increasing $F_{\text {OEGMA }}>20 \%$ (Figure 2A) and OEGMA chain-length (Figure 2B). P(DMAEMA-co-OEGMA) gene vectors were smaller in size than $\mathrm{p}$ (DMAEMA) gene vector complexes (Figure 2A). The correlation between $F_{\mathrm{OEGMA}}$ and OEGMA chain length with P(DMAEMA-co-OEGMA) gene vectors size may be related to the fact that, with an increasing degree of OEGMA copolymerization and OEGMA chain-length, complexation of pDNA is altered and therefore gene vectors lose their spherical shape. ${ }^{23}$ Apparently, low degrees of OEGMA copolymerization did not prevent pDNA condensation, which is in agreement with the results from the agarose gel retardation assay. 
The surface charge of P(DMAEMA-co-OEGMA) gene vectors gradually decreased with increasing $F_{\text {OEGMA }}$ and/or OEGMA molecular weight. This observation likely reflects the "shielding effect" of the OEGMA segments of the P(DMAEMA-coOEGMA) copolymers. In the case of the P(DMAEMA) gene vectors, zeta potentials of $\sim 25 \mathrm{mV}$ were measured, indicating a high positive surface charge of the gene vectors (Figure 2A). Similar values have been previously reported by others. ${ }^{7,9,10}$ Moreover, the above-mentioned shielding effect of the OEGMA segments correlated with $F_{\text {OEGMA }}$, resulting in gene vectors with lower surface charge close to the isoelectric point with $F_{\text {OEGMA }}$ $>50 \%$ (Figure 2). Thus, it seems likely that the P(DMAEMAco-OEGMA) copolymers form core-shell structures with OEG units orientated toward the complex surface, thereby shielding the cationic net charge of the gene vectors. In agreement with this observation, high OEGMA molecular weight (i.e., OEGMA with higher number of EG units) led to even negatively charged particles (Figure 2B). Such negative surface charge possibly results from loosely packed gene vectors with residual noncomplexed pDNA present at the nanoparticle surface. Because the zeta potential measurements were carried at low ionic strength, the surface charge of the particles under conditions used for transfection experiments was apparently lower than the values shown in Figure 2. Thus, the data should not be considered in absolute values but only as indications for the net particle charge.

Further, gene vectors derived from P(DMAEMA-co-OEGMA) copolymers were found to be kinetically stable under isotonic saline conditions. No increase in particles size was observed within $30 \mathrm{~min}$ after formation presumably due to steric stabilization by the multiple-uncharged hydrophilic OEGMA segments within the polymer scaffold (Supporting Information, Figure 2). Even low molecular weight OEGMA segments were sufficient to provide stabilization of the gene vectors. Under identical conditions, complexes prepared with P(DMAEMA) resulted in large aggregates of approximately $600 \mathrm{~nm}$, which continuously grew in size. These findings are in accordance with results previously published in literature and confirm the importance of nonelectrostatic shielding components within the cationic polymer to form compact stable gene vector particles. Even at high initial pDNA concentrations of up to $1 \mathrm{mg} / \mathrm{mL}$, P(DMAEMA-co-OEGMA) copolymer derived gene vectors remained kinetically stable (data not shown) without precipitation, whereas nonaggregated P(DMAEMA) gene vector complexes of up to $200 \mu \mathrm{g} \mathrm{pDNA} / \mathrm{mL}$ were observed only at low nonphysiological $\mathrm{pH} .^{10}$

In summary, surface charge and particle diameter could be controlled by varying both the OEGMA molecular weight and $F_{\text {OEGMA }}$. Colloidal stability of P(DMAEMA-co-OEGMA) gene vectors is presumably a result of steric stabilization by OEG units $^{13}$ and only to lesser extent because of remaining segments of positively charged polymer groups that were not involved in pDNA binding but may act as a repulsive barrier to prevent aggregation. $^{20,56}$

Further, we studied the influence of P(DMAEMA-coOEGMA) copolymer composition on morphology of the gene vectors using electron microscopy to confirm our suggestions made from particle size and surface charge measurements. The homopolymer P(DMAEMA) showed compact globular particles of approximately $600 \mathrm{~nm}$ in diameter (Figure 3A,E). These observations are consistent with size measurements by dynamic light scattering ( $600 \mathrm{~nm})$. OEGMA-copolymerisation significantly reduced the diameter of the gene vectors to $100-200$ $\mathrm{nm}$ (Figure 3E). Increasing $F_{\mathrm{OEGMA}}$ resulted in gradual loss of
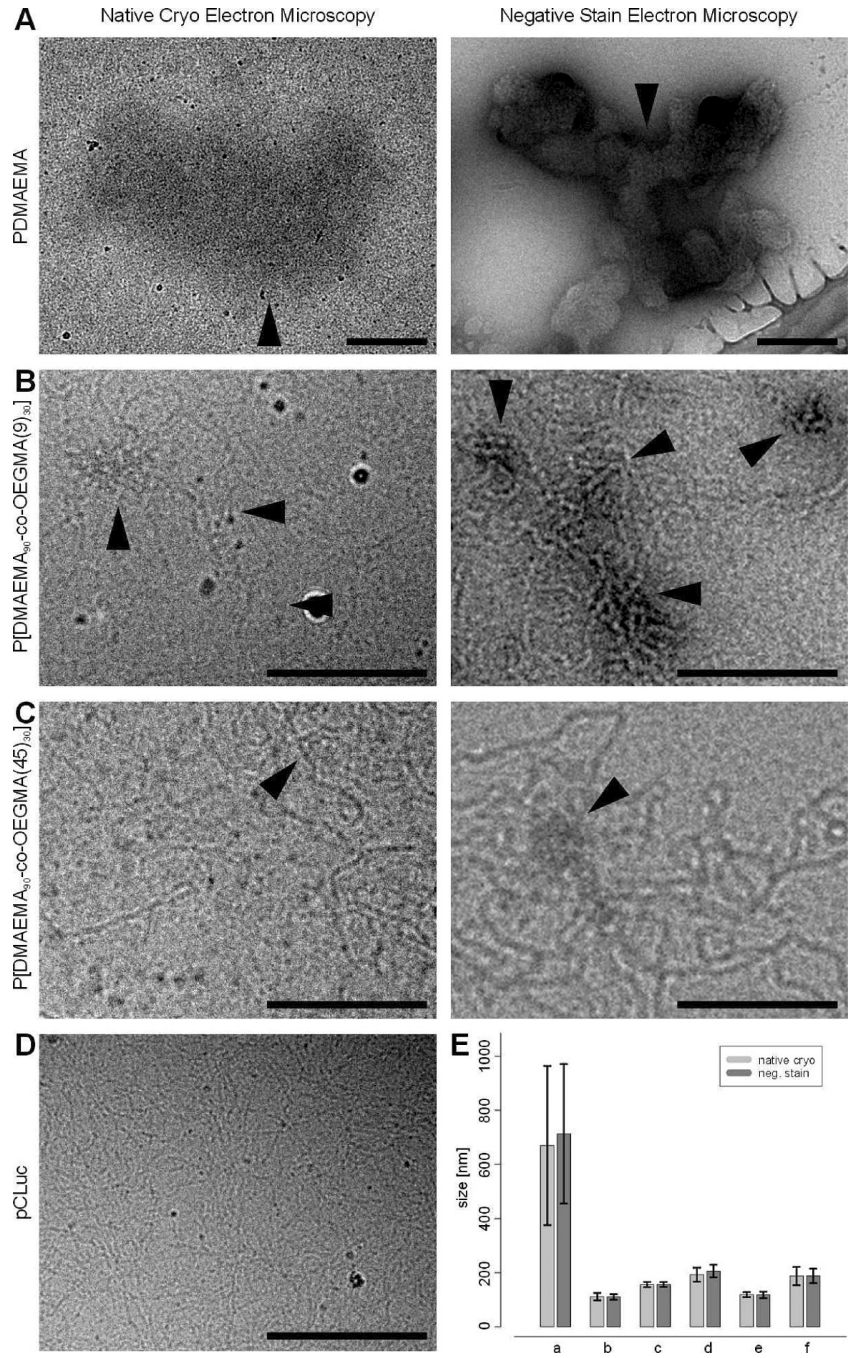

Figure 3. Electron microscopy analysis of $P(D M A E M A) / p D N A(A)$ and $P$ (DMAEMA-co-OEGMA)/pDNA complexes $(B, C)$ prepared in HBS at N/P ratio of 20 . Gene vectors were visualized using native cryo preparation (left images) and negative staining (right images), respectively. Individual complexes are marked with arrowheads. The scale bars corresponds to $200 \mathrm{~nm}$ on the specimen level. Plasmid DNA (pCLuc) is shown as a control (D). Size measurements of gene vector complexes visualized by negative staining and native cryoelectron microscopy (E): (a) P(DMAEMA); (b) P[DMAEMA ${ }_{90}-\mathrm{CO}^{-}$ $\operatorname{OEGMA}(9)_{30}$ ]; (c) P[DMAEMA $\left.{ }_{60}-\operatorname{co}-\operatorname{OEGMA}(9)_{60}\right]$; (d) P[DMAEMA ${ }_{30^{-}}$ co-OEGMA(9) 60] $_{0}$; (e) P[DMAEMA $90^{-}$-Co-OEGMA(23) ${ }_{30}$ ]; (f) P[DMAEMA ${ }_{90}-$ co-OEGMA $\left.(45)_{30}\right]$. Results are presented as means \pm standard deviation.

the compact, globular gene vector shape, and appearance of filamentous structures which can be attributed to reduced pDNA condensation and is in agreement with an increase in gene vector size. P(DMAEMA-co-OEGMA) copolymers with low $F_{\text {OEGMA, }}$ showed both compact pDNA complexes of globular shape (Figure 3B) and associated poorly or noncondensed pDNA, whereas copolymers with high $F_{\text {OEGMA }}$ exhibited predominately shapeless structures of assembled pDNA (Figure 3C,D).

Evaluation of Cytotoxicity. Like for other cationic polymers, the use of P(DMAEMA) and br-PEI as gene transfer agents has been reported to be limited by their cell toxicity even at low concentrations. ${ }^{9,57}$ Cytotoxicity has been reported to be predominantly a result of the positive polymer charge, ${ }^{7-9}$ which can be only partially masked by complexation of the cationic polymer with pDNA. ${ }^{9,58}$ Nevertheless, gene therapy requires efficient gene delivery systems without induction of any adverse effects. It was therefore expected that increasing $F_{\text {OEGMA }}$ should 
yield a decrease of cationic charge density and, thus, lead to a decrease of P(DMAEMA-co-OEGMA) cytotoxicity. Cytotoxicity of free P(DMAEMA), br-PEI, and P(DMAEMA-coOEGMA) copolymers was investigated on human bronchial epithelial cells (Supporting Information, Figure 3). Whereas P(DMAEMA) and the "gold standard" br-PEI $25 \mathrm{kDa}$ resulted in higher toxicity $(0.8 \%$ and $3.7 \%$ cell viability at the highest concentration tested), none of the P(DMAEMA-co-OEGMA) copolymers tested were cytotoxic, even at high polymer concentrations independently of the degree of grafting $\left(F_{\text {OEGMA }}\right)$ and OEGMA molecular weight (Supporting Information, Figure 3).

Transfection Efficiency of P(DMAEMA-co-OEGMA) Gene Vectors In Vitro. Transfection efficiency of P(DMAEMA-co-OEGMA) copolymers was analyzed in comparison to P(DMAEMA) and br-PEI in vitro on human bronchial epithelial cells. Transfection efficiency of P(DMAEMA) gene vectors was highest at N/P $=20$ but 10 -fold lower compared with br-PEI gene vector complexes at N/P = 10 (Figure 4A). These observations were in agreement with previously published results. ${ }^{8,59}$ Transfection efficiency of P(DMAEMA-co-OEGMA) copolymer gene vectors was dependent on the N/P ratio and decreased gradually with increasing $F_{\text {OEGMA }}$ (Figure $4 \mathrm{~A}$ ). In agreement with the results from pDNA binding, high N/P ratios (in the range of 10-40) were necessary to achieve high transfection levels. Although OEGMA copolymerization reduced transfection efficiency of P(DMAEMA-co-OEGMA) copolymer gene vectors, similar transfection rates as those observed for P(DMAEMA) were achieved with low $F_{\text {OEGMA }}$ and OEGMA molecular weight at N/P ratios of $10-40\left(F_{\text {OEGMA }} \leq 33.3 \%\right.$; EG units = 9).

To consider the variability of transfection activity between different cell types and assess the influence of $F_{\text {OEGMA }}$ and OEGMA molecular weight on another cell line, transfection studies were further carried out on murine alveolar epithelial cells at N/P ratios of 10 and 20 (Figure 4B). Similar results were found in both cell lines. Transfection efficiency of P(DMAEMA-co-OEGMA) copolymer gene vectors was dependent on the N/P ratio, $F_{\text {OEGMA }}$ and OEGMA molecular weight, respectively, but independent of the cell line tested. Only low transfection levels were observed for OEGMA-rich copolymers $\left(F_{\text {OEGMA }}>25 \%\right)$ at a N/P ratio of 10 and 20 in both cell lines (Figure $4 \mathrm{~B}$ ). Furthermore, at similar $F_{\text {OEGMA, gene }}$ transfer efficiency of P(DMAEMA-co-OEGMA) copolymers decreased with increasing OEGMA molecular weight (Figure 4C). Low transfection efficiencies observed for P(DMAEMAco-OEGMA) copolymers with high $F_{\text {OEGMA }}$ compared with P(DMAEMA-co-OEGMA) copolymers with low $F_{\text {OEGMA }}$ may not be a result of differences in particle size that were found to be within the same range. The decrease in transfection efficiency may be accounted by the less compact particle structure and completely shielded particle surface charge at high $F_{\text {OEGMA }}$. It has been reported that particle shielding reduces attachment of the gene vector complex to the cell surface. ${ }^{18,23,52,60}$ Obviously, gene vector shielding counteracts interactions with cell surfaceassociated proteoglycans which have been previously demonstrated to be involved in initializing cellular gene vector uptake. In addition, a decrease in the number of tertiary amine groups resulted in weakening of pDNA binding. Thus, poor gene expression observed from P(DMAEMA-co-OEGMA) copolymers with high $F_{\text {OEGMA }}\left(F_{\text {OEGMA }}>25 \%\right.$, EO units $\left.>9\right)$ may further be caused by dissociation of pDNA from the cationic polymer in serum-free media before cell internalization. Nevertheless, transfection levels similar to that of the P(DMAEMA)

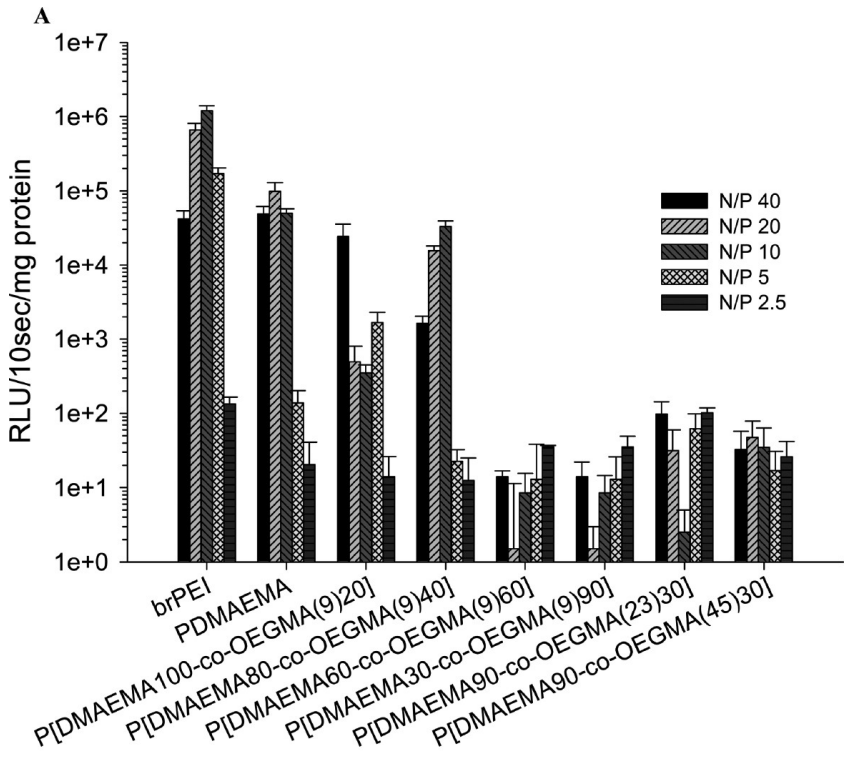

B

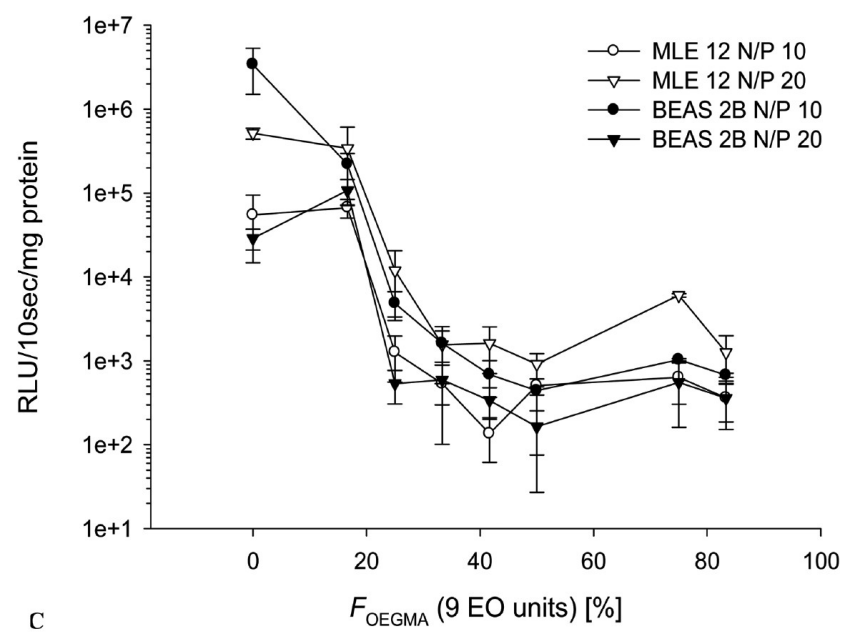

C

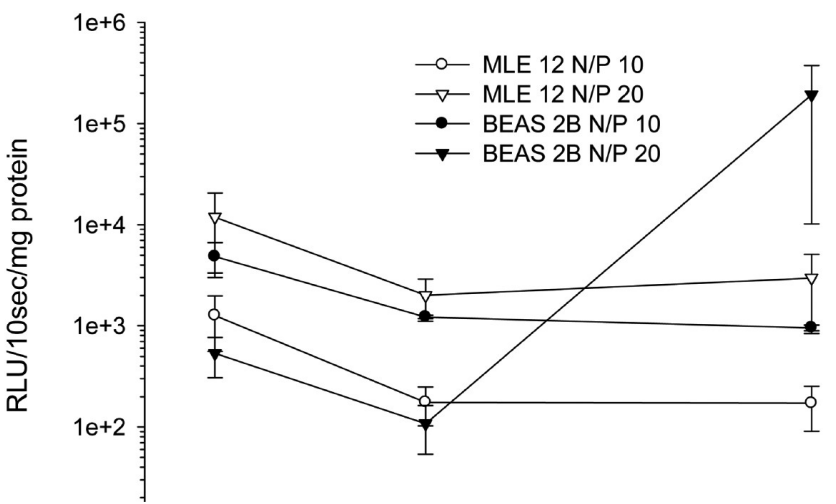

Figure 4. (A) In vitro gene transfection efficiencies of $P(D M A E M A-$ co-OEGMA) gene vector complexes in comparison with br-PEI 25 $\mathrm{kDa}$ at various $\mathrm{N} / \mathrm{P}$ ratios in BEAS-2B cells. The data are given as mean \pm SEM $(n=4)$. (B) Transfection efficiencies of P(DMAEMAco-OEGMA) gene vector complexes on BEAS-2B and MLE 12 cells with a N/P ratio of 10 and 20 as a function of $F_{\mathrm{OEGMA}}$ (9 EO units) and $(C)$ ethylene oxide units/OEGMA $\left(F_{\text {OEGMA }}=25 \%\right)$. The data are given as mean \pm SEM from one (MLE 12) to two (BEAS 2B) individual experiments (each $n=4$ ).

and approximately 10-fold less than that of br-PEI could be achieved with P(DMAEMA-co-OEGMA) composed of $16.66 \%$ OEGMA and 9 EG units in the OEGMA segment. 
Cellular Association and Internalization of P(DMAEMAco-OEGMA) Gene Vectors. Successful gene transfer into eukaryotic cells and expression of the transferred pDNA is the result of a multistep process, including (i) complex formation, (ii) cell surface binding and internalization, (iii) intracellular trafficking and transfer into the cell nucleus, and (iv) transcription and translation of the transferred pDNA. ${ }^{13}$ Characterization of P(DMAEMA-co-OEGMA) gene vectors indicated that pDNA condensation, surface charge, and transfection efficiency were largely dependent on OEGMA copolymerization, but cytotoxicity and particle size were less affected by OEGMA copolymerization. Although P(DMAEMA-co-OEGMA) copolymers mediated cell transfection and gene expression, their performances were below those of br-PEI $25 \mathrm{kDa}$. To better understand and overcome the limitations of P(DMAEMA-coOEGMA) copolymer-based gene vectors, a detailed investigation of their cell binding and internalization was performed. Furthermore, we wanted to clarify whether there was a direct correlation between transfection activity and cellular gene vector uptake. From earlier studies it was expected that both parameters decrease with increasing OEGMA copolymerization. ${ }^{28,61}$ In contrast, Petersen and co-workers suggested that high PEG ratios for PEI- $g$-PEG copolymers may lead to enhanced cellular uptake and, thus, enhanced transfection levels. ${ }^{23}$ The critical question, however, was to assess to what extent cellular uptake of P(DMAEMA-co-OEGMA) gene vectors might be affected by $F_{\text {OEGMA }}$. For this purpose, the influence of $F_{\text {OEGMA }}$ on cellular gene vector binding and internalization was investigated using flow cytometry (FACS).

The results of fluorescence quenching method (FQ) and cell scrub buffer method (CSB) are given in Figure 5A,B. The percentage of cell population showing cellular fluorescence $(\%$ TOTO-1 positive cells) decreased with increasing $F_{\text {OEGMA }}$ and OEGMA molecular weight, whereby a drastic 100-fold decrease was observed for $F_{\text {OEGMA }}=33-42 \%$ and a value of OEGMA EG units of 9-23. This observation is likely a result of shielded positive surface gene vector charge, which reduces cell surface binding of P(DMAEMA-co-OEGMA) gene vectors compared to nonshielded P(DMAEMA) gene vectors. However, the mean fluorescence intensity of each of the cells decreased only 2-3fold, indicating that the amount of internalized gene vector complexes per TOTO-1 positive cell was less affected by OEGMA-copolymerization compared to cell surface binding. These findings suggest that the initial step of cell surface binding is strongly inhibited by OEGMA-copolymerization. These observations confirm the importance of slightly positive zeta potential for gene vector complexes to be efficiently internalized into cells and are in agreement with previous studies. ${ }^{18}$ However, the results with $\mathrm{P}(\mathrm{DMAEMA}-\mathrm{co}$-OEGMA) gene vectors at optimized conditions for transfection with $F_{\text {OEGMA }}<41 \%$ and OEGMA EG units < 23 revealed that cellular uptake was comparable with br-PEI (Trypan blue: 67.1 \pm 3.7 TOTO-1 positive cells; MFI $5374 \pm 789$ ) although transfection efficiency was $>10$-fold lower. Therefore, the present data suggest that lower transfection activity of the P(DMAEMA-co-OEGMA) gene vectors may not just account for low cellular uptake but additional subsequent processes after cellular internalization may affect gene transfer efficiency and be less efficient for P(DMAEMA-co-OEGMA) gene vectors than for PEI gene vectors. Among these, endolysosomal escape has been previously described to be critical for nonviral gene vectors in terms of their gene transfer efficiency. In particular, PEI gene vectors have been demonstrated to overcome this barrier very efficiently due to their high buffering capacity in the $\mathrm{pH}$ range of acidified
A
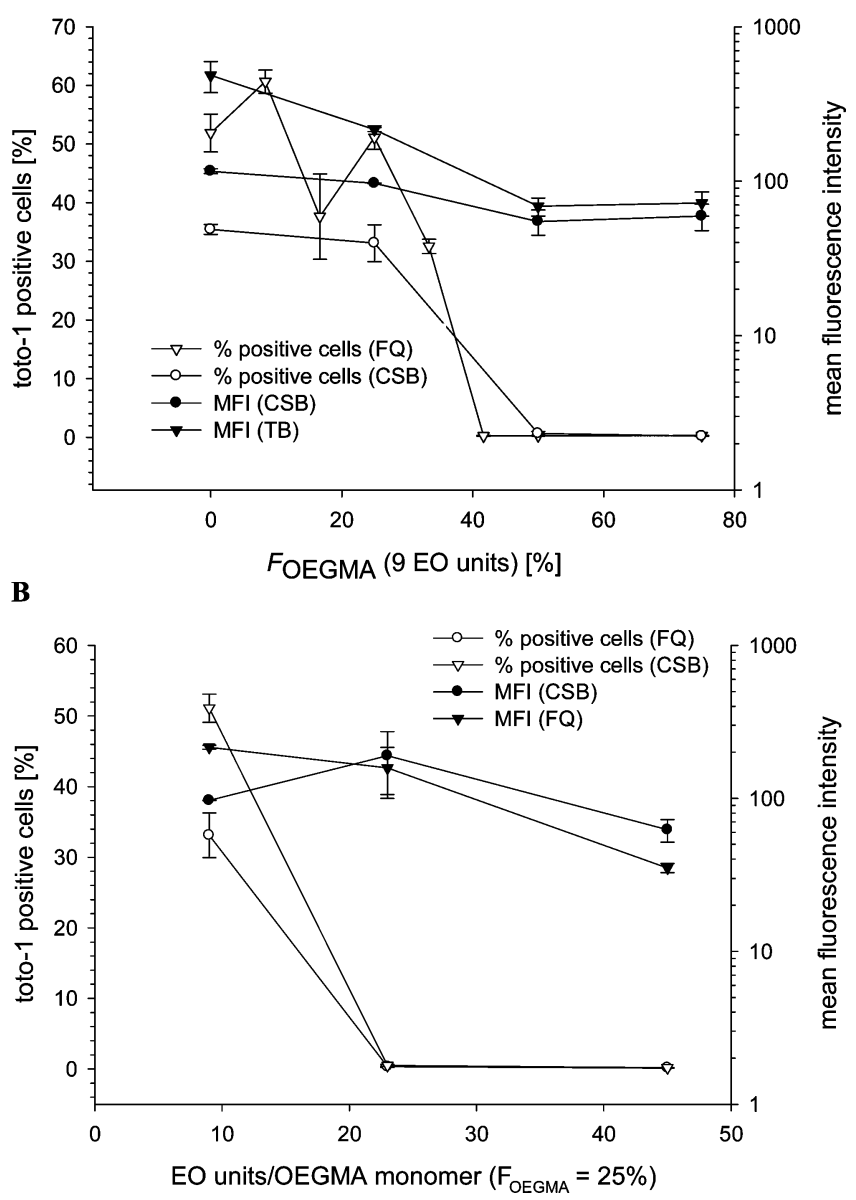

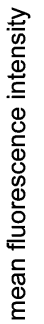

Figure 5. Cellular uptake studies using flow cytometry: $(A)$ cellular uptake of $\mathrm{P}$ (DMAEMA-co-OEGMA) complexes as a function of $F_{\text {OEGMA }}$ (9 EO units), and (B) ethylene oxide units/OEGMA monomer ( $F_{\text {OEGMA }}$ $=25 \%$ ) using fluorescence quenching method (FQ) and cell scrub buffer method (CSB).

endosomes which leads to the so-called "proton sponge effect" and successful endosomal release. Indeed, it may be conceivable that the buffering capacity of P(DMAEMA-co-OEGMA) copolymers is lower compared to PEI and, thus, represents the critical limitation for high transfection efficiency. Further studies are needed to address this issue in more detail. Moreover, it is likely that the inability of the P(DMAEMA-co-OEGMA) copolymers to condense pDNA as efficiently as PEI leads to immediate pDNA release upon cellular uptake accompanied by early onset of pDNA degradation and, thus, lower transfection efficiency. Further studies will be necessary to investigate the intracellular fate of P(DMAEMA-co-OEGMA) gene vectors upon cellular uptake in future in order to elucidate the critical step of the transfection process.

In Vivo Application. In a next step, we investigated gene transfer efficiency of P(DMAEMA-co-OEGMA) in the lungs of Balb/c mice. We used the MicoSprayer Aerolizer, which has been previously used for drug delivery to the smaller airways. ${ }^{46}$ Whereas only low luciferase activity was observed in mice that were treated with PEI gene vectors, a strong signal for lucifrease activity was evident in mice treated with P[DMAEMA ${ }_{80}-\mathrm{Co}^{-}$ OEGMA $(9)_{40}$ ] (EG units $=9$ and $F_{\text {OEGMA }}=33.3 \%$ ) gene vectors (Figure 6A,B). After $24 \mathrm{~h}$, 7-fold higher transfection efficiency could be observed for P(DMAEMA-co-OEGMA) gene vectors in lung homogenates compared to the control group brPEI in vivo. In contrast to PEI-pDNA particles that showed rather large diameters of $202 \pm 2 \mathrm{~nm}, \mathrm{P}\left[\mathrm{DMAEMA}_{80}-\mathrm{Co}\right.$ - 


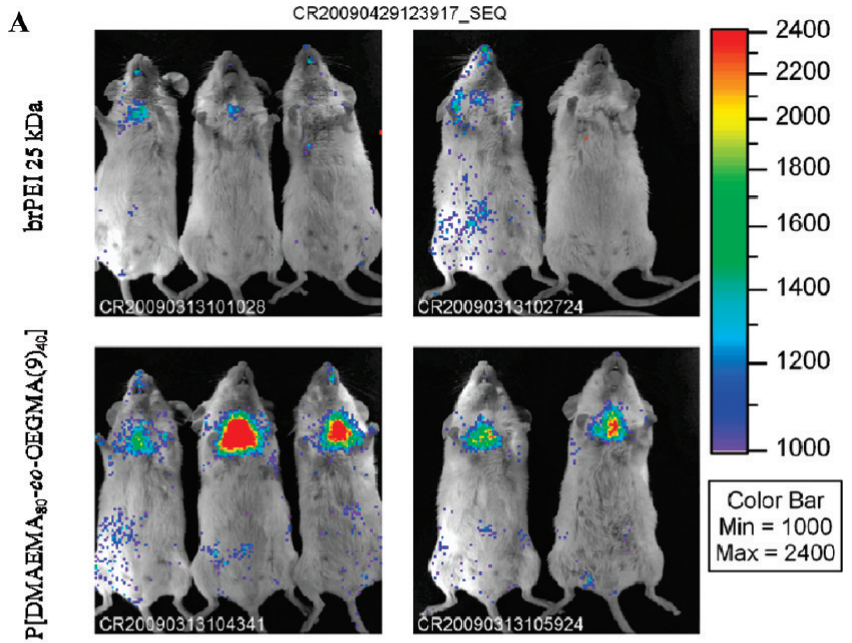

B

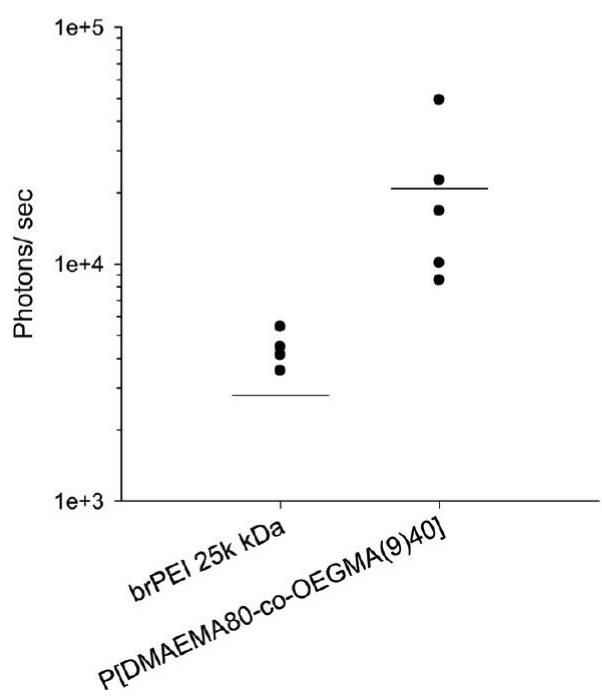

Figure 6. In vivo bioluminescence images of Balb/c mice $(A)$ and luciferase expression in the lungs (B) after intratracheal application of $12.5 \mu \mathrm{g} \mathrm{pCpGLuc.} \mathrm{Gene} \mathrm{vector} \mathrm{complexes} \mathrm{were} \mathrm{prepared} \mathrm{in} \mathrm{HBS}$ at $\mathrm{N} / \mathrm{P}$ ratio of 20 and 10 using $\mathrm{P}\left(\mathrm{DMAEMA} \mathrm{A}_{80}-\mathrm{Co}-\mathrm{OEGMA}(9)_{40}\right)$ polymer and brPEI $25 \mathrm{kDa}$, respectively. For luciferase expression, the lung region was selected and background subtraction applied by selecting an appropriate background on the same mouse. Results are given as photons per sec in mean \pm standard deviation.

OEGMA $\left.(9)_{40}\right]$ gene vectors were small, $106 \pm 2 \mathrm{~nm}$, under these conditions. These observations suggest that the size of the gene vector particles has a distinct effect on the in vivo gene transfer efficiency. However, in this context, it has to be considered that gene vectors were generated in saline. It has been previously suggested that using PEI mediated gene delivery is increased when water for injection is used for formulation compared to saline because of transient induction of a "hypoosmotic shock" which may facilitate intracellular gene vector uptake. $^{62}$ Therefore, PEI-mediated gene expression might be lower in our experiments compared with optimized conditions using water for injection. It is therefore even more promising that $\mathrm{P}\left[\mathrm{DMAEMA} \mathrm{D}_{8}-\mathrm{Co}-\mathrm{OEGMA}(9)_{40}\right]$ gene vectors resulted in pronounced gene expression in the lungs using saline as more tolerable solvent than water for injection. However, additional effects such as adsorption of components of the bronchoalveolar lavage fluid to the particle surface may be important which have to be addressed in more detail in future studies. Furthermore, future studies will allow the assessment of their relevance in context with therapeutic application in mouse models of human lung diseases.

In summary, the in vivo results underline that PEGylation of cationic polymers can enhance colloidal stability under conditions which are required for in vivo application (high salt and pDNA concentrations) and, therefore, improve gene transfer to the lung.

\section{Conclusion}

Copolymerisation of oligo(ethylene glycol) methyl ether methacrylate (OEGMA) and $N, N$-dimethylaminoethyl methacrylate (DMAEMA) by atom transfer radical polymerization (ATRP) resulted in a series of well-defined P(DMAEMA-coOEGMA) copolymers with different molecular structures, which were capable of condensing pDNA into gene vector particles of nanometer size. Increase of the molar OEGMA ratio and OEGMA chain length correlated inversely with gene vector characteristics such as size, morphology, and zeta potential, thereby allowing to form tailor-made gene vector complexes. In contrast to P(DMAEMA) and PEI gene vectors, P(DMAEMA-co-OEGMA) copolymers prevented gene vector aggregation at high concentrations in isotonic saline and did not induce cytotoxicity even at high concentrations. Whereas transfection efficiency of most efficient P(DMAEMA-coOEGMA) copolymers was found to be $>10$-fold lower compared with br-PEI $25 \mathrm{kDa}$, this discrepancy does not simply appear to represent the exclusive cause of the reduced cellular uptake of the P(DMAEMA-co-OEGMA) copolymer gene vectors. Although OEGMA copolymerisation reduced gene vector binding with the cell surface at high $F_{\text {OEGMA }}$, this was not observed for low $F_{\text {OEGMA }}$. These observations suggest that inefficient endolysosomal escape and pDNA condensation may affect their transfection efficiency. In conclusion, structural tailoring of multiblock copolymers via ATRP provides a unique and versatile method to design gene transfer agents with excellent colloidal stability and low cytotoxicity and therefore meet the requirements for in vivo application. We could demonstrate that these particles are stable even under high salt and pDNA concentration and as a result showed improved gene expression in the lungs compared to the gold standard brPEI after intratracheal application. Improving intracellular uptake, cell specificity and intracellular trafficking of the P(DMAEMAco-OEGMA) copolymers gene vector complexes by using targeting ligands together with endolysosomal disrupting peptides may be an approach to further improve their transfection efficiency.

Acknowledgment. This work was supported by the BMBF BioFuture program (FKZ 0311898), LMUexcellent and DFG Grants LU 1195/1 and RU 911 4/1 to C.R. as well as by the BMBF BioFuture program (0311899) to H.S.

Supporting Information Available. Agarose gel electrophoresis of $\mathrm{P}$ (DMAEMA-co-OEGMA) copolymers gene vector complexes at different N/P ratios are shown in Figure 1A,B. The colloidal stability of P(DMAEMA-co-OEGMA) copolymers measured by dynamic light scattering as a function of time is provided in Figure 2. The influence of P(DMAEMA-coOEGMA) copolymers on cell viability as a function of polymer concentration measured by ATP activity is shown in Figure 3. This material is available free of charge via the Internet at http:// pubs.acs.org. 


\section{References and Notes}

(1) Lungwitz, U.; Breunig, M.; Blunk, T.; Gopferich, A. Polyethyleniminebased non-viral gene delivery systems. Eur. J. Pharm. Biopharm. 2005, 60 (2), 247-66.

(2) Dubruel, P.; Schacht, E. Vinyl polymers as non-viral gene delivery carriers: Current status and prospects. Macromol. Biosci. 2006, 6 (10), 789-810.

(3) Felgner, P. L.; Barenholz, Y.; Behr, J. P.; Cheng, S. H.; Cullis, P.; Huang, L.; Jessee, J. A.; Seymour, L.; Szoka, F.; Thierry, A. R.; Wagner, E.; Wu, G. Nomenclature for synthetic gene delivery systems. Hum. Gene Ther. 1997, 8 (5), 511-2.

(4) Dash, P. R.; Read, M. L.; Barrett, L. B.; Wolfert, M. A.; Seymour, L. W. Factors affecting blood clearance and in vivo distribution of polyelectrolyte complexes for gene delivery. Gene Ther. 1999, 6 (4), 643-50.

(5) Dubruel, P. pH sensitive vinyl copolymers as vectors for gene therapy. J. Bioact. Compat. Polym. 2000, 15, 191.

(6) Lutz, J.-F. Solution self-assembly of tailor-made macromolecular building-blocks prepared by controlled radical polymerization techniques. Polym. Int. 2006, 55 (9), 979-993.

(7) Cherng, J. Y.; van de Wetering, P.; Talsma, H.; Crommelin, D. J.; Hennink, W. E. Effect of size and serum proteins on transfection efficiency of poly ((2-dimethylamino)ethyl methacrylate)-plasmid nanoparticles. Pharm. Res. 1996, 13 (7), 1038-42.

(8) Van de Wetering, P.; Cherng, J. Y.; Talsma, H.; Hennink, W. E. Relation between transfection efficiency and cytotoxicity of poly(2dimethylamino)ethyl mathycrylate)/plasmid complexes. J. Controlled Release 1997, 49, 59-69.

(9) van de Wetering, P.; Cherng, J. Y.; Talsma, H.; Crommelin, D. J.; Hennink, W. E. 2-(Dimethylamino)ethyl methacrylate based (co)polymers as gene transfer agents. J. Controlled Release 1998, 53 (1-3), 145-53.

(10) Cherng, J. Y.; Talsma, H.; Verrijk, R.; Crommelin, D. J.; Hennink, W. E. The effect of formulation parameters on the size of poly-((2dimethylamino)ethyl methacrylate)-plasmid complexes. Eur. J. Pharm. Biopharm. 1999, 47 (3), 215-24.

(11) Verbaan, F. J.; Klouwenberg, P. K.; van Steenis, J. H.; Snel, C. J.; Boerman, O.; Hennink, W. E.; Storm, G. Application of poly(2(dimethylamino)ethyl methacrylate)-based polyplexes for gene transfer into human ovarian carcinoma cells. Int. J. Pharm. 2005, 304 (1-2), 185-92.

(12) Choksakulnimitir, S.; Masuda, S.; Tokuda, H.; Takakura, Y.; Hashida M. In vitro cytotoxicity of macromolecules in different culture systems. J. Controlled Release 1995, 34, 233-241.

(13) Merdan, T.; Kopecek, J.; Kissel, T. Prospects for cationic polymers in gene and oligonucleotide therapy against cancer. Adv. Drug Delivery Rev. 2002, 54 (5), 715-58.

(14) Kircheis, R.; Wightman, L.; Wagner, E. Design and gene delivery activity of modified polyethylenimines. Adv. Drug Delivery Rev. 2001, 53 (3), 341-58.

(15) Verbaan, F. J.; Oussoren, C.; van Dam, I. M.; Takakura, Y.; Hashida, M.; Crommelin, D. J.; Hennink, W. E.; Storm, G. The fate of poly(2dimethyl amino ethyl)methacrylate-based polyplexes after intravenous administration. Int. J. Pharm. 2001, 214 (1-2), 99-101.

(16) Verbaan, F.; van Dam, I.; Takakura, Y.; Hashida, M.; Hennink, W.; Storm, G.; Oussoren, C. Intravenous fate of poly(2-(dimethylamino)ethyl methacrylate)-based polyplexes. Eur. J. Pharm. Sci. 2003, 20 (4-5), 419-27.

(17) Ogris, M.; Brunner, S.; Schuller, S.; Kircheis, R.; Wagner, E. PEGylated DNA/transferrin-PEI complexes: Reduced interaction with blood components, extended circulation in blood and potential for systemic gene delivery. Gene Ther. 1999, 6 (4), 595-605.

(18) Zuidam, N. J.; Posthuma, G.; de Vries, E. T.; Crommelin, D. J.; Hennink, W. E.; Storm, G. Effects of physicochemical characteristics of poly(2-(dimethylamino)ethyl methacrylate)-based polyplexes on cellular association and internalization. J. Drug Target. 2000, 8 (1), $51-66$.

(19) Tang, M. X.; Szoka, F. C. The influence of polymer structure on the interactions of cationic polymers with DNA and morphology of the resulting complexes. Gene Ther. 1997, 4 (8), 823-32.

(20) Rungsardthong, U.; Ehtezazi, T.; Bailey, L.; Armes, S. P.; Garnett, M. C.; Stolnik, S. Effect of polymer ionization on the interaction with DNA in nonviral gene delivery systems. Biomacromolecules 2003, 4 (3), 683-90.

(21) Lee, M. Polyethylene glycol-conjugated copolymers for plasmid DNA delivery. Pharm. Res. 2004, 22 (1), 1-10.

(22) Fisher, K. D.; Ulbrich, K.; Subr, V.; Ward, C. M.; Mautner, V.; Blakey, D.; Seymour, L. W. A versatile system for receptor-mediated gene delivery permits increased entry of DNA into target cells, enhanced delivery to the nucleus and elevated rates of transgene expression. Gene Ther. 2000, 7 (15), 1337-43.

(23) Petersen, H.; Fechner, P. M.; Martin, A. L.; Kunath, K.; Stolnik, S.; Roberts, C. J.; Fischer, D.; Davies, M. C.; Kissel, T. Polyethyleniminegraft-poly(ethylene glycol) copolymers: Influence of copolymer block structure on DNA complexation and biological activities as gene delivery system. Bioconjugate Chem. 2002, 13 (4), 845-54.

(24) Katayose, S.; Kataoka, K. Water-soluble polyion complex associates of DNA and poly(ethylene glycol)-poly(L-lysine) block copolymer. Bioconjugate Chem. 1997, 8 (5), 702-7.

(25) Choi, J. S.; Lee, E. J.; Choi, Y. H.; Jeong, Y. J.; Park, J. S. Poly(ethylene glycol)-block-poly(L-lysine) dendrimer: Novel linear polymer/dendrimer block copolymer forming a spherical water-soluble polyionic complex with DNA. Bioconjugate Chem. 1999, 10 (1), 62, zlpg $>5$.

(26) Kichler, A.; Chillon, M.; Leborgne, C.; Danos, O.; Frisch, B. Intranasal gene delivery with a polyethylenimine-PEG conjugate. J. Controlled Release 2002, 81 (3), 379-88.

(27) Zhang, X. Poly(ethylene glycol)-block-polyethylenimine copolymers as carriers for gene delivery: Effects of PEG molecular weight and PEGylation degree. J. Biomed. Mater. Res., Part A 2008, 84 (3), 795804.

(28) Choi, Y. H.; Liu, F.; Kim, J. S.; Choi, Y. K.; Park, J. S.; Kim, S. W. Polyethylene glycol-grafted poly-L-lysine as polymeric gene carrier. J. Controlled Release 1998, 54 (1), 39-48.

(29) Toncheva, V.; Wolfert, M. A.; Dash, P. R.; Oupicky, D.; Ulbrich, K.; Seymour, L. W.; Schacht, E. H. Novel vectors for gene delivery formed by self-assembly of DNA with poly(L-lysine) grafted with hydrophilic polymers. Biochim. Biophys. Acta 1998, 1380 (3), 354-68.

(30) Pirotton, S.; Muller, C.; Pantoustier, N.; Botteman, F.; Collinet, S.; Grandfils, C.; Dandrifosse, G.; Degee, P.; Dubois, P.; Raes, M. Enhancement of transfection efficiency through rapid and noncovalent post-PEGylation of poly(dimethylaminoethyl methacrylate)/DNA complexes. Pharm. Res. 2004, 21 (8), 1471-9.

(31) Kircheis, R.; Blessing, T.; Brunner, S.; Wightman, L.; Wagner, E. Tumor targeting with surface-shielded ligand-polycation DNA complexes. J. Controlled Release 2001, 72 (1-3), 165-70.

(32) Kircheis, R.; Schuller, S.; Brunner, S.; Ogris, M.; Heider, K. H.; Zauner, W.; Wagner, E. Polycation-based DNA complexes for tumortargeted gene delivery in vivo. J. Gene Med. 1999, 1 (2), 111-20.

(33) Konstan, M. W.; Davis, P. B.; Wagener, J. S.; Hilliard, K. A.; Stern, R. C.; Milgram, L. J.; Kowalczyk, T. H.; Hyatt, S. L.; Fink, T. L.; Gedeon, C. R.; Oette, S. M.; Payne, J. M.; Muhammad, O.; Ziady, A. G.; Moen, R. C.; Cooper, M. J. Compacted DNA nanoparticles administered to the nasal mucosa of cystic fibrosis subjects are safe and demonstrate partial to complete cystic fibrosis transmembrane regulator reconstitution. Hum. Gene Ther. 2004, 15 (12), 1255-69.

(34) Agarwal, A.; Unfer, R.; Mallapragada, S. K. Novel cationic pentablock copolymers as non-viral vectors for gene therapy. J. Controlled Release 2005, 103 (1), 245-58.

(35) Jiang, X.; Lok, M. C.; Hennink, W. E. Degradable-brushed pHEMApDMAEMA synthesized via ATRP and click chemistry for gene delivery. Bioconjugate Chem. 2007, 18 (6), 2077-84.

(36) Rudolph, C.; Schillinger, U.; Ortiz, A.; Plank, C.; Golas, M. M.; Sander, B.; Stark, H.; Rosenecker, J. Aerosolized nanogram quantities of plasmid DNA mediate highly efficient gene delivery to mouse airway epithelium. Mol. Ther. 2005, 12 (3), 493-501.

(37) Valentine, R. C.; Shapiro, B. M.; Stadtman, E. R. Regulation of glutamine synthetase. XII. Biochemistry 1968, 7 (6), 2143-52.

(38) Adrian, M.; Dubochet, J.; Lepault, J.; McDowall, A. W. Cryo-electron microscopy of viruses. Nature 1984, 308 (5954), 32-6.

(39) Huth, S.; Lausier, J.; Gersting, S. W.; Rudolph, C.; Plank, C.; Welsch, U.; Rosenecker, J. Insights into the mechanism of magnetofection using PEI-based magnetofectins for gene transfer. J. Gene Med. 2004, 6 (8), 923-36.

(40) Hed, J. The extinction of fluorescence by crystal violet and its use. to differentiate between attached and ingested micro-organism in phagocytosis. FEMS Microbiol. Lett. 1977, 1, 357-361.

(41) Hed, J.; Hallden, G.; Johansson, S. G.; Larsson, P. The use of fluorescence quenching in flow cytofluorometry to measure the attachment and ingestion phases in phagocytosis in peripheral blood without prior cell separation. J. Immunol. Methods 1987, 101 (1), 11925.

(42) Innes, N. P.; Ogden, G. R. A technique for the study of endocytosis in human oral epithelial cells. Arch. Oral Biol. 1999, 44 (6), 519-23.

(43) Kopatz, I.; Remy, J. S.; Behr, J. P. A model for non-viral gene delivery: Through syndecan adhesion molecules and powered by actin. J. Gene Med. 2004, 6 (7), 769-76. 
(44) Harris, S. S.; Giorgio, T. D. Convective flow increases lipoplex delivery rate to in vitro cellular monolayers. Gene Ther. 2005, 12 (6), 512-20.

(45) Scott, E. S.; Wiseman, J. W.; Evans, M. J.; Colledge, W. H. Enhanced gene delivery to human airway epithelial cells using an integrintargeting lipoplex. J. Gene Med. 2001, 3 (2), 125-34.

(46) Bivas-Benita, M.; Zwier, R.; Junginger, H. E.; Borchard, G. Noninvasive pulmonary aerosol delivery in mice by the endotracheal route. Eur. J. Pharm. Biopharm. 2005, 61 (3), 214-8.

(47) Matyjaszewski, K.; Xia, J. Atom transfer radical polymerization. Chem. Rev. 2001, 101 (9), 2921-2990.

(48) Matyjaszewski, K. Macromolecular engineering: From rational design through precise macromolecular synthesis and processing to targeted macroscopic material properties. Prog. Polym. Sci. 2005, 30 (8-9), $858-875$.

(49) Lutz, J.-F.; Hoth, A. Preparation of ideal PEG analogues with a tunable thermosensitivity by controlled radical copolymerization of 2-(2methoxyethoxy)ethyl methacrylate and oligo(ethylene glycol) methacrylate. Macromolecules 2006, 39 (2), 893-896.

(50) Lutz, J.-F.; Andrieu, J.; Üzgün, S.; Rudolph, C.; Agarwal, S Biocompatible, thermoresponsive, and biodegradable: Simple preparation of "all-in-one" biorelevant polymers. Macromolecules 2007, 40 (24), 8540-8543.

(51) Lutz, J.-F. Polymerization of oligo(ethylene glycol) (meth)acrylates: Toward new generations of smart biocompatible materials. J. Polym. Sci., Part A: Polym. Chem. 2008, 46 (11), 3459-3470.

(52) Verbaan, F. J.; Oussoren, C.; Snel, C. J.; Crommelin, D. J.; Hennink, W. E.; Storm, G. Steric stabilization of poly(2-(dimethylamino)ethyl methacrylate)-based polyplexes mediates prolonged circulation and tumor targeting in mice. J. Gene Med. 2004, 6 (1), 64-75.

(53) Stolnik, S.; Daudali, B.; Arien, A.; Whetstone, J.; Heald, C. R.; Garnett, M. C.; Davis, S. S.; Illum, L. The effect of surface coverage and conformation of poly(ethylene oxide) (PEO) chains of poloxamer 407 on the biological fate of model colloidal drug carriers. Biochim. Biophys. Acta 2001, 1514 (2), 261-79.
(54) Kurisawa, M.; Yokoyama, M.; Okano, T. Transfection efficiency increases by incorporating hydrophobic monomer units into polymeric gene carriers. J. Controlled Release 2000, 68 (1), 1-8.

(55) Ogris, M.; Steinlein, P.; Kursa, M.; Mechtler, K.; Kircheis, R.; Wagner, $\mathrm{E}$. The size of DNA/transferrin-PEI complexes is an important factor for gene expression in cultured cells. Gene Ther. 1998, 5 (10), 142533.

(56) Jones, N. A.; Hill, I. R.; Stolnik, S.; Bignotti, F.; Davis, S. S.; Garnett, M. C. Polymer chemical structure is a key determinant of physicochemical and colloidal properties of polymer-DNA complexes for gene delivery. Biochim. Biophys. Acta 2000, 1517 (1), 1-18.

(57) Godbey, W. T.; Wu, K. K.; Mikos, A. G. Poly(ethylenimine) and its role in gene delivery. J. Controlled Release 1999, 60 (2-3), 149-60.

(58) Boussif, O.; Lezoualch, F.; Zanta, M. A.; Mergny, M. D.; Scherman, D.; Demeneix, B.; Behr, J. P. A versatile vector for gene and oligonucleotide transfer into cells in culture and in vivo: Polyethylenimine. Proc. Natl. Acad. Sci. U.S.A. 1995, 92 (16), 7297-301.

(59) Dubruel, P.; Christiaens, B.; Vanloo, B.; Bracke, K.; Rosseneu, M.; Vandekerckhove, J.; Schacht, E. Physicochemical and biological evaluation of cationic polymethacrylates as vectors for gene delivery. Eur. J. Pharm. Sci. 2003, 18 (3-4), 211-20.

(60) Tang, G. P.; Zeng, J. M.; Gao, S. J.; Ma, Y. X.; Shi, L.; Li, Y.; Too, H. P.; Wang, S. Polyethylene glycol modified polyethylenimine for improved CNS gene transfer: Effects of PEGylation extent. Biomaterials 2003, 24 (13), 2351-62.

(61) Lemieux, P.; Vinogradov, S. V.; Gebhart, C. L.; Guerin, N.; Paradis, G.; Nguyen, H. K.; Ochietti, B.; Suzdaltseva, Y. G.; Bartakova, E. V.; Bronich, T. K.; St-Pierre, Y.; Alakhov, V. Y.; Kabanov, A. V. Block and graft copolymers and NanoGel copolymer networks for DNA delivery into cell. J. Drug Target. 2000, 8 (2), 91-105.

(62) Rudolph, C.; Lausier, J.; Naundorf, S.; Muller, R. H.; Rosenecker, J. In vivo gene delivery to the lung using polyethylenimine and fractured polyamidoamine dendrimers. J. Gene Med. 2000, 2 (4), 269-78. 